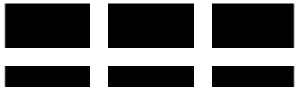 \\ THE WILLIAM DAVIDSON INSTITUTE \\ AT THE UNIVERSITY OF MICHIGAN
}

\section{Contagion Across and Integration of Central and Eastern European Stock Markets: Evidence from Intraday Data}

\author{
By: Balazs Egert and Evzen Kocenda
}

William Davidson Institute Working Paper Number 798

November 2005 


\title{
Contagion Across and Integration of Central and Eastern European Stock Markets: Evidence from Intraday Data
}

\author{
Balázs Égert* Evžen Kočenda*
}

\begin{abstract}
We analyze interrelations between three stock markets in Central and Eastern Europe and, in addition, interconnections which may exist between Western European (DAX, CAC, UKX) and Central and Eastern European stock markets (BUX, PX-50, WIG20). The novelty of our paper rests mainly on the use of the five-minute tick intraday price data from the mid-2003 to the early 2005 for stock indices and on the wide range of econometric techniques employed. We find no robust cointegration relationship for any of the stock index pairs or for any of the extended specifications. There are signs of short-term spillover effects both in terms of stock returns and stock price volatility. Granger causality tests show the presence of bidirectional causality for returns as well as volatility series. The results based on a VAR framework indicate a more limited number of short-term relationships between the stock markets. In general, it appears that spillover effects are stronger from volatility to volatility than contagion effects from return to return series.
\end{abstract}

JEL codes: C22, F36, G15, O16, P59

Keywords : contagion and spillover effects, market integration, European emerging markets, intra-day data

* Oesterreichische Nationalbank; EconomiX, University of Paris X-Nanterre and the William Davidson Institute; Tel. (+43) 1 404205246; e-mail: balazs.egert@oenb.at ; begert@u-paris10.fr

- Corresponding author, CERGE-EI Charles University and Academy of Sciences, Politickych veznu 7, P.O.Box 882, 11121 Prague,

Czech Republic.

Tel. (+420) 224.005.149, 224.005.212, fax: (+420) 224.227.143; e-mail: evzen.kocenda@cerge-ei.cz

We are grateful to Oxana Babetskaia-Kukharchuk, Ian Babetskii, Jesús Crespo-Cuaresma, Roy Gardner, Petr Zemčík and participants of the GDN International Workshop (2005, Prague) for helpful comments and to Rena Mühldorf for excellent language assistance. We gratefully acknowledge GDN grant support of the project "Modeling Stock Market Returns and Volatility: The Case of Selected Industrialized and New EU Member States". The usual disclaimer applies. 


\section{Introduction}

Stock markets in Central and Eastern Europe (CEE), especially those in Budapest, Prague and Warsaw, underwent some remarkable developments both in terms of market capitalisation and daily trade volumes from the very beginning of the economic transformation. Although the financial system of these countries largely remains bank dominated, the stock exchanges appear to be well integrated with world financial markets following the lifting of restrictions on portfolio capital movements. However, given that these markets are small compared to the stock exchanges of the largest OECD countries, they are sensitive to shifts in regional and world-wide portfolio adjustments of large investments fund and other market participants, even though the amount of capital involved in such moves are by no means very large by global standards. This underpins the popular wisdom according to which these markets are more volatile than well-established stock markets.

By now, some empirical research focusing on volatility of the transition economies has become available. For instance, Murinde and Poshakwale (2001) investigate the volatility characteristics of individual countries using an array of GARCH models. Bohl and Henke (2003) investigate the relationship between daily returns and trading volume for 20 Polish stocks. They show that in the majority of cases volatility persistence tends to disappear when trading volume is included in the conditional variance equation, a result that is in agreement with the findings of studies on developed stock markets. Scheicher (2001) studies the regional and global integration of stock markets in Hungary, Poland and the Czech Republic and finds evidence of limited interaction: in returns, both regional and global shocks are identified, but innovations to volatility exhibit a chiefly regional character. The markets exhibit low correlations with international markets as well. Tse, $\mathrm{Wu}$, and Young (2003) investigate the international information transmission between the US and Polish stock markets using daily return data. They show that there is no volatility spillover between these two markets and that 
these two markets are not driven by a long-run common trend. However, there is a mean spillover running from the New York Stock Exchange to the Warsaw Stock Exchange (WSE) in the EGARCH model (weak evidence of the short-run influence of the US market on the performance of the WSE). By contrast, the WSE has virtually no influence on the US market.

The evidence in the literature is pre-dominantly based on data with daily or even lower frequencies, since historical series from the CEE stock markets with higher frequencies are usually unavailable. Thus, developments in volatility and contagion effects that materialize during the trading day represent a finer picture that often cannot be extracted from daily observations. Another, and more general advantage of using intraday data is that the estimates are more robust given the relatively short time horizon (2 years) as compared to studies employing daily data (up to 10 years) decreases the probability of structural breaks (Terzi, 2003).

Our research is motivated by the general lack of inference that can be drawn from the intra-day data. We investigate links and possible spillover effects for stock returns and stock volatilisations among markets in Budapest, Prague and Warsaw. We also study their interactions with selected major markets in the EU on the basis of intraday data of intraday data recorded in five-minute intervals for the period from mid-2003 to early 2005 . We do not find any robust cointegration relationship for any of the stock index pairs but we identify short-term spillover effects both in terms of stock returns and stock price volatility. Volatilityto-volatility contagion effects dominate those of returns-to-returns. The robustness of our results is warranted by a battery of econometric techniques used.

The outline of the paper is as follows: Section 2 provides a general overview on the general developments and the specific features of Budapest, Prague and Warsaw stock exchanges. Section 3 deals with data issues. Section 4 focuses on the testing procedure. Section 5 presents the estimation results. Finally, section 6 gives some concluding remarks. 


\section{Stock Markets in Central and Eastern Europe}

\subsection{General Developments}

In this section, we shall provide a brief overview on the developments and main characteristics of the three stock exchanges under investigation in this paper. Let us first direct our attention to the Budapest stock exchange. Hungary began its transformation earlier than other CEE countries when it adopted a series of important laws to establish an institutional framework for transfer of ownership from state to private subjects in the late $1980 \mathrm{~s}^{1}{ }^{1}$ The country was also ahead of others in founding its stock exchange. In December 1987, 22 banks concluded an agreement about controlled stock exchange trading, but the Securities Act, which provided the legal framework for the establishment of the Budapest Stock Exchange (BSE), entered into force only in March 1990. Trading began in June 1990, and computerized settlement was launched in November 1991. The Budapest Stock Exchange index (BUX) started to be published in January 1995 and in April 1997 it began to be calculated on a continuous basis (every five seconds). In March 2001 trading on the unregulated market system began, allowing for trading in foreign securities. The BSE restructured its category system in April 2001. Under the new framework, the shares were classified into the categories "A" and "B", based on a modified set of criteria. Additionally, a so-called "T" segment for equities with large growth potential was created. The Federation of European Stock Exchanges (FESE) accepted the Budapest Stock Exchange as its first associate member in June 1999; full membership came with the accession of Hungary to the EU in May 2004.

\footnotetext{
${ }^{1}$ Hungary adopted the Bankruptcy Law in 1986, but did not enforce it at that time. Further, Hungary adopted the Company Law in 1988 (it allowed for the establishment of new joint stock companies) and the Transformation law in 1989 (it enabled state firms to be transformed into joint stock companies). In 1988 all forms of ownership were legalized and made equal.
} 
The Prague Stock Exchange was established on November 24, 1992, as a place where the shares of firms privatized in the large-scale privatization move were to be traded. ${ }^{2}$ Thus, its original purpose was to serve more as a secondary market. On April 6, 1993, trading opened in seven securities issues. In June and July, 1993, 622 and 333 share issues, respectively, from the $1^{\text {st }}$ wave of voucher privatization were launched on the stock exchange. The exchange's official PX-50 Index started to be computed and reported on April 5, 1994; continuous computing began in early 1999. In April 1995, 674 share issues from the $2^{\text {nd }}$ wave of voucher privatization were launched. The number of shares was clearly too high, and in 1997, 1,301 illiquid share issues were withdrawn from the free market. Mid-1998, the stock exchange opened a market segment on which Czech blue chips started to be traded. In June 2001, the Prague Stock Exchange was affiliated as the Associate Member of FESE and automatically became a full member of FESE in connection with the accession of the Czech Republic to the European Union in May 2004.

In November 1990 Poland and France signed an intergovernmental agreement to create the Warsaw Stock Exchange (WSE). Its founding act was signed in April 1991, and the first trading session took place immediately, with five companies listed (at first, sessions were once a week). The computer settlement system was launched in August the same year. The frequency of trading sessions increased gradually to five sessions a week in 1994. Along with the Warsaw Stock Index (WIG), the WIG20 blue chip index was launched (continuous publication began in early 1997). Continuous trading (of the first five companies) began in 1996. In 1999 the WSE became an associate member of FESE. A major change in trading that increased efficiency and market transparency was the launch of the new Warsaw Stock

\footnotetext{
${ }^{2}$ Large-scale privatization began in 1991 and was completed in early 1995 . The privatization program allowed for various privatization techniques. Small firms were usually auctioned or sold in tenders. Many medium-sized businesses were sold in tenders or to pre-determined buyers in direct sales. Most large and many medium-sized firms were transformed into joint stock companies and their shares were distributed through voucher privatization, sold in public auctions or to strategic partners, or transferred to municipalities. For relevant details on the privatization process, see Kočenda (1999), and Filer and Hanousek (2001).
} 
Exchange Trading System (WARSET) at the end of 2000. Further, in early 2003 the WSE introduced a post-auction trading phase in the continuous trading system. The WSE became a full member of FESE in 2004 after Poland joined the EU.

\subsection{Market Size and Specific Features}

The Central European stock markets are small when compared with mature stock markets in Europe or the USA. However, they have been expanding dramatically since the transforming economies have emerged from transition and have begun their integration into the European structures. The ratio of market capitalization to GDP differs in each country and reflects the dominant privatization method used in the early transition period as well as degree to which the stock market serves as a source to raise capital. Table 1 shows how market capitalization as well as its ratio to GDP has developed over the transition period in the three stock markets in question.

In Hungary, market capitalization started to rise sharply during the 1994 to 1996 period and literally jumped in 1997 as newly privatized firms entered the market. Later on, the degree of capitalization somewhat levelled off, but it has remained quite high, as firms seek to raise new capital on the market. The proportion of the foreign issues in total market capitalization is very small. The ratio of market capitalization to the GDP peaked in 1999 but is currently the lowest of the three Central European markets.

Market capitalization increased markedly during the 1994 to 1996 period in the Czech Republic after several thousands of firms privatized during the large-scale privatization campaign were put on the stock market. The majority of these stocks were illiquid, though. Substantial delisting in 1997 and later reduced the number of traded shares dramatically. ${ }^{3}$

\footnotetext{
${ }^{3}$ Four major waves of massive delisting took place on March 20, April 1, June 2, and October 1, 1997. Altogether 1,301 issues were excluded from trading. In the first wave, 100 free market issues were delisted, in
} 
Market capitalization dropped and subsequently increased substantially in 2003 to 2004, chiefly thanks to the entry of foreign issues on the Prague market. The ratio of market capitalization to GDP decreased gradually during the 1995 to 2001 period, but is currently highest among the three markets in question.

In Poland market capitalization rose sharply from 1995 to 2000 (a more than six-fold increase). It declined temporarily in 2001 to almost triple in 2004. The early increase of market capitalization resulted from the introduction of privatized firms on the stock market. The recent increase should be to some extent credited to the fact that foreign companies started to be traded on the market in 2003. The ratio of market capitalization to the GDP is currently second to that of the Czech Republic.

Table 1. Market Capitalisation of the CEE Stock Markets

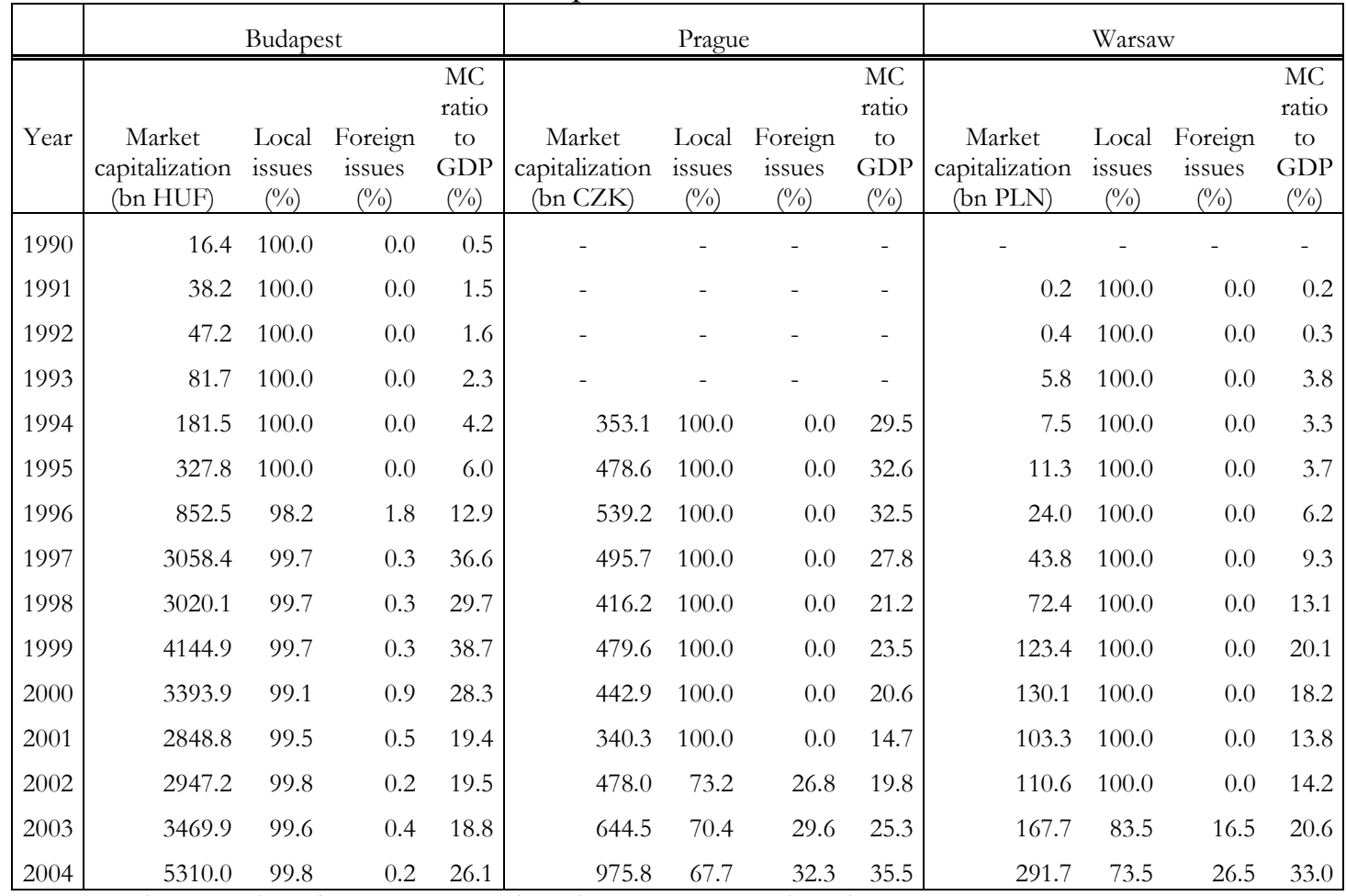

Source: Budapest Stock Exchange, Prague Stock Exchange, Warsaw Stock Exchange

Note: HUF, CZK and PLN stand for Hungarian forint, Czech koruna and Polish złoty, respectively. MC stands for market capitalization.

the second wave it was 391 issues, the third wave concerned 509 share issues, and the last one included 301 issues. For more details see Hanousek and Němeček (2001). 
Aside from some institutional similarities, all three markets tend to exhibit specific features of integration, co-movement and investment strategies, which have been extensively analyzed in applied research. For instance, Syriopoulos (2004) found that the individual Central European markets tend to display stronger linkages with their mature counterparts than with neighbouring markets. Such long-run co-movements imply that diversifying risk and attaining superior portfolio returns by investing in different Central European markets may be limited for international investors. This is in line with findings of Affaneh, Boldin and Majercak (2003) that effective asset diversification could benefit the mature international investor but that the magnitude of benefits differs depending on the origin of the investor. They argue that the German investor could benefit most from diversification under the condition that no short sales are allowed. ${ }^{4}$

There is mixed evidence on the assumption that stock markets in the CEECs are not efficient. For instance, Smith and Ryoo (2003) test the hypothesis that stock market price indices of the European emerging markets followed a random walk during the 1990s using the multiple variance ratio test. In Hungary and Poland (along with Greece and Portugal), the random walk hypothesis is rejected because of autocorrelation in returns. By contrast, Rockinger and Urga (2000) develop a methodology based on a time-varying parameter model to investigate market efficiency over the period from April 1994 through June 1999 in emerging European markets. They find that the Hungarian market always satisfies weak efficiency. For the Czech and Polish markets, they document convergence toward efficiency.

\footnotetext{
${ }^{4}$ Portfolios were constructed using data for the 1994 to 2000 period under the assumption of short sales versus no short sales.
} 


\section{Intraday Data}

Our dataset is composed of intraday data for the stock markets of three Central and Eastern Europe and three industrialised countries as quoted by Bloomberg. ${ }^{5}$ Stock exchange index quotes are available in five-minute intervals (ticks) for stock indices at the stock markets in Budapest (BUX), Prague (PX 50), Warsaw (WIG-20), London (FTSE 100), Frankfurt (DAX 30), and Paris (CAC-40).

The time period of our data starts on June 2, 2003, at 1:30 p.m. and ends on February 9, 2005, at 1:00 p.m. of the Central European Daylight Time (CEDT). Table 2 gives an overview of the trading hours of the six stock indices. Trading hours are longer in Western Europe than in the CEE markets. In order to make our analysis fully comparable and executable, we use the common denominator, which is the window for the WIG20 running from 10:00 a.m. to 3.55 p.m. For such a window, we are left with 29,466 observations for each stock index. Table 3 shows some descriptive statistics according to which the log stock returns are highly non-normal, which justifies the use of GARCH models to investigate volatility spillovers between the stock markets under study.

Table 2. Time matches

\begin{tabular}{|c|c|c|c|}
\hline & Start & End & Ticks \\
\hline BUX & 9.00 & 16.25 & 90 \\
\hline PX-50 & 9.30 & 16.00 & 79 \\
\hline WIG20 & 10.00 & 15.55 & 72 \\
\hline DAX & 9.00 & 20.10 & 135 \\
\hline CAC & 9.05 & 17.25 & 101 \\
\hline UKX & 9.00 & 17.35 & 104 \\
\hline
\end{tabular}

\footnotetext{
${ }^{5}$ With the exception of the Černý and Koblas (2005), we are not aware of other published studies that use intraday data from the Central European stock markets under research.
} 
Table 3. Descriptive statistics

\begin{tabular}{|l|cccccc|cccccc|}
\hline & \multicolumn{6}{|c|}{ Log levels } & \multicolumn{7}{c|}{ Log differences } \\
& BUX & PX-50 & WIG20 & CAC & DAX & UKX & BUX & PX-50 & WIG20 & CAC & DAX & UKX \\
\hline Mean & 9.28 & 6.62 & 7.41 & 8.17 & 8.25 & 8.40 & 0.00 & 0.00 & 0.00 & 0.00 & 0.00 & 0.00 \\
Median & 9.27 & 6.66 & 7.43 & 8.20 & 8.26 & 8.39 & 0.00 & 0.00 & 0.00 & 0.00 & 0.00 & 0.00 \\
Maximum & 9.71 & 7.02 & 7.60 & 8.29 & 8.39 & 8.52 & 0.05 & 0.02 & 0.03 & 0.02 & 0.03 & 0.02 \\
Minimum & 8.95 & 6.27 & 7.08 & 8.01 & 8.01 & 8.29 & -0.04 & -0.03 & -0.02 & -0.02 & -0.03 & -0.03 \\
Std. Dev. & 0.19 & 0.20 & 0.11 & 0.07 & 0.08 & 0.05 & 0.00 & 0.00 & 0.00 & 0.00 & 0.00 & 0.00 \\
Skewness & 0.23 & 0.15 & -1.00 & -0.70 & -0.73 & 0.11 & 2.54 & -3.67 & 0.71 & 0.34 & 0.10 & -1.49 \\
Kurtosis & 2.16 & 2.05 & 3.52 & 2.45 & 2.72 & 2.49 & 172.12 & 205.09 & 32.94 & 107.13 & 109.81 & 158.88 \\
Jarque-Bera & 1127.75 & 1213.98 & 5248.10 & 2761.93 & 2713.96 & 371.06 & 35144541 & 50205418 & 1102800 & 13313521 & 14005259 & 29841992 \\
p-value & 0.00 & 0.00 & 0.00 & 0.00 & 0.00 & 0.00 & 0.00 & 0.00 & 0.00 & 0.00 & 0.00 & 0.00 \\
Obs & 29466 & 29466 & 29466 & 29466 & 29466 & 29466 & 29465 & 29465 & 29465 & 29465 & 29465 & 29465 \\
\hline
\end{tabular}

\section{Econometric Methods}

\subsection{Unit Root and Stationarity Tests}

In our econometric investigation we follow a multi-stage approach. We first perform some standard unit root and stationarity tests: the augmented Dickey-Fuller (ADF) and PhilipsPerron (PP) unit root tests and the Kwiatkowski, Phillips, Schmidt, and Shin (KPSS) stationarity test. Since these methods belong among the standard tools, we will not elaborate on them further and present results of these tests in the next section.

Further, we are indeed interested in possible long-term relationships between the individual stock indices. For this purpose, we perform pairwise cointegration tests between the CEE stock indices and between the individual stock indices and their three Western European counterparts. In addition, a cointegration relationship including all three CEE stock indices and one Western European stock index will be analysed.

\subsection{Cointegration Tests}

We implement four alternative cointegration techniques described below. Such an approach enables us to check whether possible cointegration findings are sensitive to the estimation technique. The starting point is the Engle-Granger residual-based cointegration method, 
which asserts that a dependent variable $Y_{t}$ and exogenous variables $X_{i, t}$ form a long-term relationship if the residuals obtained from equation (1) are stationary:

$$
Y_{t}=\beta_{0}+\sum_{i=1}^{n} \beta_{i} X_{i, t}+e_{t}
$$

This can be tested by using standard unit root and stationarity tests such as those introduced in section 4.1.

Specification (1) does not account for potential endogeneity of the right-hand side variable. This shortcoming is alleviated in alternative cointegration methods. The dynamic ordinary least squares (DOLS) introduced by Stock and Watson (1993) accounts for the endogeneity of the regressors and serial correlation in the residuals in equation (1) by incorporating lags and leads of the regressors in first differences:

$$
Y_{t}=\beta_{0}+\sum_{i=1}^{n} \beta_{i} X_{i, t}+\sum_{i=1}^{n} \sum_{j=-k_{1}}^{k_{2}} \gamma_{i, j} \Delta X_{i, t-j}+\varepsilon_{t}
$$

where $\mathrm{k}_{1}$ and $\mathrm{k}_{2}$ denote, respectively, leads and lags. The length of leads and lags is determined on the basis of the Schwarz, Akaike and Hannan-Quinn information criteria. The presence of cointegration is assessed upon stationarity of the residuals ${ }^{\varepsilon_{t}}$ obtained from the long-term relationship, in a way similar to the Engle-Granger approach (see equation 1).

Another method allowing the mixture of $\mathrm{I}(0)$ and $\mathrm{I}(1)$ variables is the autoregressive distributed lag (ARDL) approach proposed by Pesaran et al. (2001). The error correction form of the ARDL model is given by equation (3): the dependent variable in first differences is regressed on the lagged values of the dependent and independent variables in levels and first differences.

$$
\Delta Y_{t}=\beta_{0}+\rho\left(Y_{t-1}+\sum_{i=1}^{n} \beta_{i} X_{i, t-1}\right)+\sum_{j=1}^{l_{1}} \eta_{j} \Delta Y_{t-j}+\sum_{i=1}^{n} \sum_{j=0}^{l_{2}} \gamma_{i, j} \Delta X_{i, t-j}+\varepsilon_{t}
$$


To detect the presence of cointegrating relationships, Pesaran et al. (2001) employ the socalled bounds testing approach. Using conventional F-tests, the null of $H_{0}: \rho=\beta_{1}=\ldots=\beta_{n}=0$ is tested against the alternative hypothesis of $H_{1}: \rho \neq 0, \beta_{1} \neq 0, \ldots, \beta_{n} \neq 0$. Pesaran et al. (2001) tabulate two sets of critical values, one for the case when all variables are I(1), i.e. upper bound critical values, and another one for when all variables are $\mathrm{I}(0)$, i.e. lower bound critical values. Critical values are provided for five different models, of which specification (3) with unrestricted intercept and no trend will be used in our study. If the test statistic is higher than the upper bound critical value, the null of no cointegration is rejected in favour of the presence of cointegration. On the other hand, an F-statistic lower than the lower bound critical value implies the absence of cointegration. In the event that the calculated F-statistic lies between the two critical values, there is no clear indication of the absence or existence of a cointegrating relationship.

An alternative to the single equation methods presented above is the Johansen cointegration technique, which is an efficient tool of testing for the number of cointegrating vectors in a VAR (vector autoregressive) framework. In the event that only one long-term relationship is found using the trace statistics, the Maximum Likelihood estimates are used as a robustness check in the following form:

$$
Y_{t}=\left(m_{0}+m_{1} t+\left(1+\alpha \beta^{\prime}\right) Y_{t-1}\right)-\sum_{i=1}^{p-1} \Phi_{i} \Delta Y_{t-i}+\varepsilon_{t}
$$

where Y represents the vector including the dependent and the independent variables. The VAR-based Johansen approach is used to verify the number of cointegration relationships that might link the variables. The detection of a single long-term relationship that turns out to be stable over time then validates results of the single-equation methods. The Johansen technique involves the roots of the VAR model to be verified (to ensure stationarity of the 
autoregressive processes), tests for normality and serial correlation. Furthermore, both the rank of cointegration and parameter constancy are analysed.

\subsection{Granger Causality Tests for Stock Prices}

In a second stage, we investigate short-term interactions between the stock markets under study. A first step of this stage is to conduct pairwise Granger causality tests. If the stock index series are stationary in levels, the level variables can be used for this exercise. Using level variables, the Granger causality test can be written as in equation (5) in accordance with which not only lagged values of $\mathrm{Y}(\mathrm{X})$ but also past values of $\mathrm{X}(\mathrm{Y})$ can impact on $\mathrm{Y}(\mathrm{X})$.

$$
\begin{aligned}
& Y_{t}=\alpha_{0}+\sum_{i=1}^{k} \alpha_{i} Y_{t-i}+\sum_{i=1}^{k} \beta_{i} X_{t-i}+\varepsilon_{t} \\
& X_{t}=\alpha_{0}+\sum_{i=1}^{k} \alpha_{i} X_{t-i}+\sum_{i=1}^{k} \beta_{i} Y_{t-i}+\varepsilon_{t}
\end{aligned}
$$

where $k$ is the lag length of the VAR. Whether or not lagged values of $\mathrm{X}(\mathrm{Y})$ are significant in statistical terms, conventional F-tests are carried out to verify if the joint null hypothesis of $H_{0}: \beta_{1}=\beta_{2}=\ldots=\beta_{k}=0$ can be rejected. If the null hypothesis is rejected, $\mathrm{X}(\mathrm{Y})$ is said to Granger-cause Y (X).

However, causality tests applied to level variables make sense only if the two variables included in the VAR system are stationary. If the series are nonstationary in levels but stationary in first differences, the Granger and Sims causality tests should be carried out within a VAR in first differences. An additional problem that arises in this context is that ignoring long-term cointegration relationships among the variables may lead to spurious causality. Thus, causality tests for I(1) variables linked with a long-term relationship should be conducted in a framework as given in equation (6): 


$$
\begin{aligned}
& \Delta Y_{t}=\alpha_{0}+\sum_{i=1}^{k} \alpha_{i} \Delta Y_{t-i}+\sum_{i=1}^{k} \beta_{i} \Delta X_{t-i}+\rho\left(X_{t}-\delta Y_{t}\right)+\varepsilon_{t} \\
& \Delta X_{t}=\alpha_{0}+\sum_{i=1}^{k} \alpha_{i} \Delta X_{t-i}+\sum_{i=1}^{k} \beta_{i} \Delta Y_{t-i}+\rho\left(Y_{t}-\delta X_{t}\right)+\varepsilon_{t}
\end{aligned}
$$

If the two I(1) variables are not connected via a cointegrating vector, a simple VAR in first difference can be used as shown in equation (7):

$$
\begin{aligned}
& \Delta Y_{t}=\alpha_{0}+\sum_{i=1}^{k} \alpha_{i} \Delta Y_{t-i}+\sum_{i=1}^{k} \beta_{i} \Delta X_{t-i}+\varepsilon_{t} \\
& \Delta X_{t}=\alpha_{0}+\sum_{i=1}^{k} \alpha_{i} \Delta X_{t-i}+\sum_{i=1}^{k} \beta_{i} \Delta Y_{t-i}+\varepsilon_{t}
\end{aligned}
$$

With this as a background, we implement a coherent testing strategy, which can be summarised in Figure 1 below.

Figure 1. Testing strategy for determining causality between currency pairs

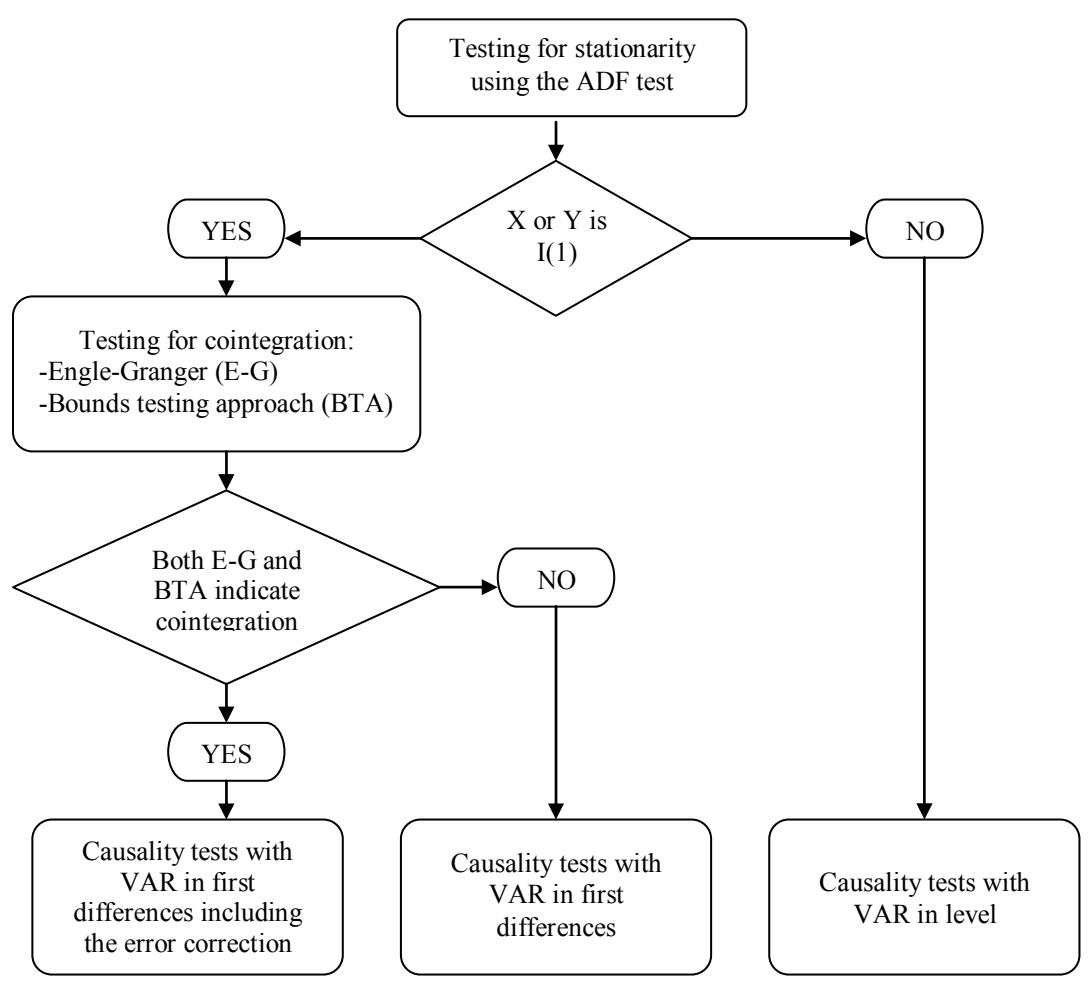

\subsection{Granger Causality Tests for Stock Market Volatility}


The Granger causality tests described earlier will also be applied to stock volatility. In this context, one may use either volatility measures based on the implied volatility of option prices or volatility derived using econometric techniques, such as the GARCH framework. We follow the second avenue mainly because of the lack of data on stock options in the countries under study in general, especially data at an intraday frequency. ${ }^{6}$ In our endeavour, we estimate the recent component GARCH (CGARCH) model of Engle and Lee (1999). Equations (8) to (10) describe the standard GARCH $(1,1)$ model, where $\Delta s_{t}, \varepsilon_{t-1}^{2}$, and $\sigma_{t-1}^{2}$ are the stock returns, the ARCH and GARCH terms, respectively.

$$
\begin{aligned}
& \Delta s_{t}=\phi_{1}+\sum_{i=1}^{m} \phi_{5, i} \Delta s_{t-i}+\varepsilon_{t} \\
& \varepsilon_{t} \Omega_{t-1} \sim N\left(0, \sigma^{2}\right) \\
& \sigma_{t}^{2}=\omega+\alpha \varepsilon_{t-1}^{2}+\beta \sigma_{t-1}^{2}
\end{aligned}
$$

The CGARCH model distinguishes between short-term and long-term conditional volatility. Contrary to constant conditional volatility in a standard GARCH model, long-term volatility $\left(q_{t}\right)$ is allowed to vary over time, to which the short-term volatility $\left(\sigma_{t}^{2}-q_{t}\right)$ or the transitory component of long-term volatility mean-reverts. CGARCH makes it possible to model separately for example the effect of interventions on exchange rate volatility in the short and long run or the long-run volatility of currency bond futures, as in McMillan and Speight (2002). The short-term conditional variance model can be written as:

$$
\sigma_{t}^{2}-q_{t}=\bar{\omega}+\alpha \cdot\left(\varepsilon_{t-1}^{2}-\bar{\omega}\right)+\beta \cdot\left(\sigma_{t-1}^{2}-\bar{\omega}\right)
$$

The time-varying long-term volatility converges to $\omega$ with $\rho$ as shown in (12):

\footnotetext{
${ }^{6}$ Valachy and Kočenda (2005) investigate exchange rate volatility among the currencies of the Visegrad Four (CZK, HUF, PLZ, SIT). The lack of stock options data prevented them from following the implied volatility of
} 


$$
q_{t}=\omega+\rho \cdot\left(q_{t-1}-\omega\right)+\delta \cdot\left(\varepsilon_{t-1}^{2}-\sigma_{t-1}^{2}\right)
$$

\subsection{VAR Estimations for Stock Returns and Volatility}

The final step of our analysis is to investigate possible spillover effects between three Western European stock markets and three stock markets in Central and Eastern Europe on the one hand, and among the three CEE stock markets themselves. With this in mind, we estimate a VAR model which includes stock returns and stock market volatility obtained after having estimated the above CGARCH model. Each VAR includes data for the three CEE and one Western European stock market, which yields a total of three estimated VARs:

$$
Y_{k, t}=A_{k, 0}+\sum_{i=1}^{p-1} A_{k, i} Y_{k, t-i}+\varepsilon_{k, t}
$$

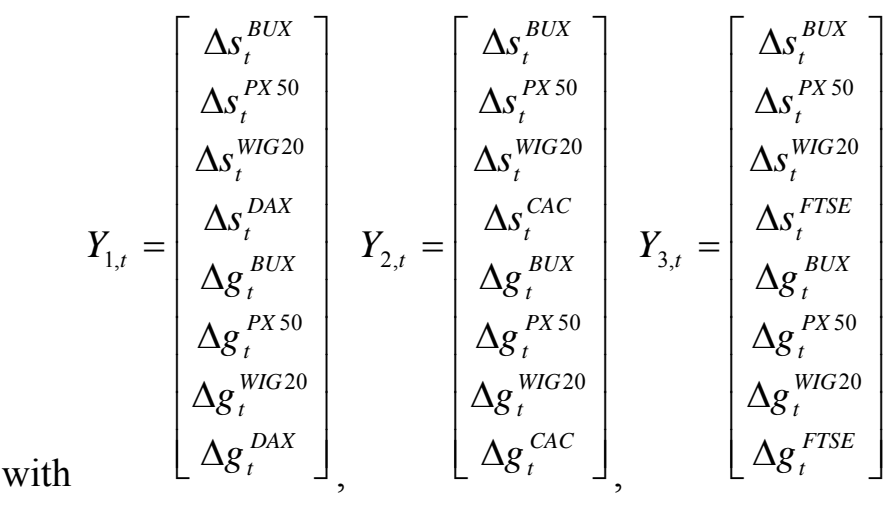

where $\Delta s_{t}$ and $\Delta g_{t}$ denote stock returns and the estimated stock market volatility.

option prices, too. In a similar manner Vojtek (2004) notes that these products are either not traded or their prices have often no explanatory power. 


\section{Empirical Findings}

\subsection{Cointegration}

As we are interested first in possible long-run relationships between the stock market indices included in this study, it appears to be necessary to check whether the individual stock index series are stationary in levels or are difference stationary. For this reason, a battery of unit root and stationarity tests is implemented. The results of this exercise, which are reported in Table 4 below, strongly confirm at the standard 5\% significance level that the stock index series are not stationary in levels, but are stationary in first differences. The unit root tests were also applied to data in second differences in order to detect any I(2) features of the data. These results are very much in line with those obtained for first-differenced data, which makes us think that the series are difference-stationary processes.

Table 4. Unit root tests

\begin{tabular}{|c|c|c|c|c|c|c|}
\hline \multicolumn{7}{|c|}{ Log Levels } \\
\hline & ADF & & $\mathrm{PP}$ & & KPSS & \\
\hline & trend & constant & trend & constant & trend & constant \\
\hline BUX & $-3.13^{*}$ & 0.18 & -3.10 & 0.05 & $2.05^{* * *}$ & $14.4^{* * *}$ \\
\hline PX-50 & -0.61 & 1.08 & -1.14 & 0.36 & $1.6^{* * *}$ & $12.85^{* * *}$ \\
\hline WIG20 & -2.59 & $-2.66^{*}$ & -2.61 & $-2.59 *$ & $1.31 * * *$ & $13.56^{* * *}$ \\
\hline DAX & -2.84 & $-2.67 *$ & -2.85 & $-2.67 *$ & $2.21 * * *$ & $12.07 * * *$ \\
\hline CAC & -2.55 & -2.25 & -2.58 & -2.26 & $1.03 * * *$ & $11.66^{* * *}$ \\
\hline UKX & -1.11 & -0.71 & -1.44 & -0.92 & $1.1 * * *$ & $10.85^{* * *}$ \\
\hline \multicolumn{7}{|c|}{$1^{\text {st }}$ differences } \\
\hline BUX & $-88.46^{* * *}$ & $-88.44 * * *$ & $-88.59 * * *$ & $-88.58^{* * *}$ & $0.17 * *$ & $0.4^{*}$ \\
\hline PX-50 & $-41.26 * * *$ & $-41.22^{* * *}$ & $-76.91 * * *$ & $-76.89 * * *$ & 0.05 & $0.17^{*}$ \\
\hline WIG20 & $-82.71 * * *$ & $-82.67 * * *$ & $-82.65^{* * *}$ & $-82.61 * * *$ & 0.07 & $0.42^{*}$ \\
\hline DAX & $-117.26 * * *$ & $-117.25^{* * *}$ & $-117.24 * * *$ & $-117.23^{* * *}$ & 0.04 & $0.16^{*}$ \\
\hline CAC & $-98.65^{* * *}$ & $-98.65^{* * *}$ & $-98.65^{* * *}$ & $-98.66 * * *$ & 0.03 & $0.09 *$ \\
\hline UKX & $-98.12^{* * *}$ & $-98.12^{* * *}$ & $-98.09 * * *$ & $-98.09 * * *$ & 0.03 & 0.03 \\
\hline \multicolumn{7}{|c|}{$2^{\text {nd }}$ differences } \\
\hline BUX & $-24.72 * * *$ & $-24.72^{* * *}$ & $-423.57 * * *$ & $-422.59 * * *$ & 0.06 & $0.16^{*}$ \\
\hline PX-50 & $-25.55^{* * *}$ & $-25.55^{* * *}$ & $-213.18^{* * *}$ & $-212.94 * * *$ & 0.04 & $0.24 *$ \\
\hline WIG20 & $-27.1 * * *$ & $-27.11 * * *$ & $-410.15^{* * *}$ & $-410.16^{* * *}$ & 0.12 & $0.12^{*}$ \\
\hline DAX & $-34.32 * * *$ & $-34.32 * * *$ & $-1097.99 * * *$ & $-1066.01 * * *$ & 0.07 & $0.12^{*}$ \\
\hline CAC & $-30.73^{* * *}$ & $-30.73^{* * *}$ & $-1047.25^{* * *}$ & $-1028.22 * * *$ & 0.06 & $0.45^{*}$ \\
\hline UKX & $-31.2^{* * *}$ & $-31.2^{* * *}$ & $-611.51 * * *$ & $-603.87 * * *$ & 0.05 & $0.38^{*}$ \\
\hline
\end{tabular}

Notes: ADF, PP; and KPPS are the Augmented Dickey-Fuller, the Phillips-Perron, and the Kwiatowski-Phillips-Schmidt-Shin unit root tests, respectively, for the case including only a constant. In parentheses is the lag length chosen using the Shwartz information criterion for the ADF test, and the Newey West kernel estimator for the PP and KPSS tests. *, ** and *** denote the rejection of the null hypothesis. For the ADF and PP tests, the null hypothesis is the presence of a unit root, whereas for the KPSS tests, the null hypothesis is stationarity. 
With this as a background, we set out to perform a variety of cointegration methods. As shown in Table 5, the single equation approaches (E-G, DOLS and bounds testing approach) usually cannot establish any robust pairwise or extended cointegrating vectors. Generally, the cointegration statistics indicate that the residuals are not stationary. However, in several cases, such as for the relationships PX-50-WIG20; BUX-PX-50-WIG20, and the bilateral relationships between the PX 50 and the WIG20 on the one hand, and three Western European stock indices on the other, the bounds testing approach provides evidence for the existence of cointegration relationships. Nonetheless, the estimated error correction terms are found in all those cases to be statistically insignificant, and this puts into question the former results. This can be observed the other way around for the E-G and DOLS estimates, where the error correction terms sometimes appear to be significantly negative but the formal cointegration tests do not validate these results. Finally, the Johansen trace statistics show that the null of no cointegration is rejected in some cases, for instance for the relationships BUXPX-50, BUX-WIG20, PX-50-WIG20, BUX-PX-50-WIG20 and for the relation linking the CEE stock indices to their Western counterparts.

Two observations deserve mention in this respect. First, these findings do not overlap with the cointegration findings from the single-equation approach, except in the case of PX50-WIG20 and BUX-PX-50-WIG20. Second, the cointegration finding is strongly mitigated by the fact that the Schwarz information criterion systematically chooses the model with no cointegration and that for the BUX-PX-50 relation the roots of the VAR model are located outside the unit circle, indicating instability of the VAR model. Finally, when we test for cointegration including all six stock indices, the results suggest the absence of any long-run relationship linking the series. Overall, the results do not provide any firm evidence for longterm cointegration relationships among stock indices studied here. 
Table 5. Cointegration Tests

\begin{tabular}{|c|c|c|c|c|c|c|c|c|}
\hline & \multirow{2}{*}{\multicolumn{2}{|c|}{ EG }} & \multirow[t]{2}{*}{ DOLS } & \multirow[t]{2}{*}{ ARDL } & \multicolumn{3}{|c|}{ JOHANSEN } & \multirow[b]{2}{*}{ ROOTS } \\
\hline & & & & & $\mathrm{R}$ & TRACE & SIC & \\
\hline \multirow[t]{3}{*}{ BUX - PX-50 } & & & $(0,0)$ & $(1,10)$ & 0 & $27.728^{* * *}$ & $-23.685^{*}$ & $\mathrm{NO}$ \\
\hline & COINT & $-2.214(1)$ & $-2.211(1)$ & -3.545 & 1 & 1.369 & -23.683 & \\
\hline & ECT & 0 & 0 & 0 & 2 & & -23.677 & \\
\hline \multirow{3}{*}{ BUX - WIG20 } & & & $(5,0)$ & $(1,10)$ & 0 & $28.81^{* * *}$ & $-21.751 *$ & OK \\
\hline & COINT & $-2.847(0)$ & $-2.86(0)$ & 2.597 & 1 & 5.758 & -21.748 & \\
\hline & ECT & $-0.001 * * *$ & $-0.001 * * *$ & $-0.001 * * *$ & 2 & & -21.743 & \\
\hline \multirow{3}{*}{ PX-50- WIG20 } & & & $(10,10)$ & $(10,10)$ & 0 & $25.592 * * *$ & $-22.966 *$ & $\mathrm{OK}$ \\
\hline & COINT & $-1.276(0)$ & $-1.379(0)$ & $191.542^{* *}$ & 1 & 6.578 & -22.962 & \\
\hline & ECT & 0 & 0 & 0 & 2 & & -22.956 & \\
\hline \multirow{4}{*}{ BUX - PX-50 - WIG20 } & & & $(10,10)$ & $(10,9)$ & 0 & $43.362 * * *$ & $-34.444 *$ & OK \\
\hline & COIN'T & $-2.385(0)$ & $-2.823(0)$ & $123.56^{* *}$ & 1 & 13.764 & -34.439 & \\
\hline & ECT & 0 & 0 & 0 & 2 & 4.529 & -34.430 & \\
\hline & & & & & 3 & & -34.421 & \\
\hline \multirow[t]{3}{*}{ BUX-DAX } & & & $(0,0)$ & $(1,10)$ & 0 & 16.776 & $-21.730 *$ & OK \\
\hline & COINT & $-2.028(0)$ & $-2.03(0)$ & 3.532 & 1 & 0.728 & -21.727 & \\
\hline & ECT & $0^{*}$ & $0^{*}$ & 0 & 2 & & -21.722 & \\
\hline \multirow[t]{3}{*}{ BUX - CAC } & & & $(0,0)$ & $(1,10)$ & 0 & 14.299 & $-22.153 *$ & $\mathrm{OK}$ \\
\hline & COINT & $-2.225(0)$ & $-2.227(0)$ & 1.23 & 1 & 0.968 & -22.149 & \\
\hline & ECT & $-0.001 * *$ & $-0.001 * *$ & 0 & 2 & & -22.144 & \\
\hline \multirow{3}{*}{ BUX - UKX } & & & $(0,0)$ & $(1,10)$ & 0 & 11.198 & $-22.955^{*}$ & $\mathrm{NO}$ \\
\hline & COINT & $-1.546(0)$ & $-1.546(0)$ & 1.07 & 1 & 0.062 & -22.952 & \\
\hline & ECT & $-0.001 * *$ & $-0.001 * *$ & 0 & 2 & & -22.947 & \\
\hline PX-50-DAX & & & $(0,0)$ & $(10,2)$ & 0 & 13.075 & $-23.194 *$ & $\mathrm{NO}$ \\
\hline & COINT & $-0.249(0)$ & $-0.25(0)$ & $874.159 * *$ & 1 & 2.087 & -23.189 & \\
\hline & ECT & 0 & 0 & 0 & 2 & & -23.183 & \\
\hline PX-50-CAC & & & $(0,0)$ & $(10,1)$ & 0 & 15.395 & $-23.555^{*}$ & $\mathrm{NO}$ \\
\hline & COINT & $-1.232(0)$ & $-1.234(0)$ & $875.929 * *$ & 1 & 3.511 & -23.550 & \\
\hline & ECT & 0 & 0 & 0 & 2 & & -23.544 & \\
\hline PX-50-UKX & & & $(0,0)$ & $(10,1)$ & 0 & 13.485 & $-24.374^{*}$ & $\mathrm{NO}$ \\
\hline & COINT & $-1.772(1)$ & $-1.772(1)$ & $870.692^{* *}$ & 1 & 2.335 & -24.369 & \\
\hline & ECT & 0 & 0 & 0 & 2 & & -24.363 & \\
\hline WIG20 - DAX & & & $(0,0)$ & $(10,3)$ & 0 & 14.113 & $-21.22113^{*}$ & $\mathrm{OK}$ \\
\hline & COINT & $-2.105(1)$ & $-2.105(1)$ & $541.063^{* *}$ & 1 & 5.419 & -21.216 & \\
\hline & ECT & $-0.001 *$ & $-0.001 *$ & 0 & 2 & & -21.210 & \\
\hline WIG20 - CAC & & & $(0,0)$ & $(10,2)$ & 0 & 15.978 & $-21.590^{*}$ & OK \\
\hline & COINT & $-2.147(0)$ & $-2.147(0)$ & $535.023^{* *}$ & 1 & 5.795 & -21.585 & \\
\hline & ECT & -0.001 & -0.001 & 0 & 2 & & -21.579 & \\
\hline WIG20 - UKX & & & $(0,0)$ & $(10,1)$ & 0 & 9.900 & $-22.426^{*}$ & OK \\
\hline & COINT & $-1.769(0)$ & $-1.769(0)$ & $530.037 * *$ & 1 & 1.988 & -22.421 & \\
\hline & ECT & $-0.001 * *$ & $-0.001 * *$ & 0 & 2 & & -22.414 & \\
\hline CEEC3 - DAX & & & $(0,10)$ & $(1,10)$ & 0 & $55.732^{* *}$ & $-45.428^{*}$ & $\mathrm{OK}$ \\
\hline & COINT & $-2.838(0)$ & $-2.945(0)$ & -1.579 & 1 & 19.519 & -45.421 & \\
\hline & ECT & 0 & 0 & 0 & 2 & 9.486 & -45.410 & \\
\hline & & & & & 3 & 4.333 & -45.397 & \\
\hline & & & & & 4 & & -45.385 & \\
\hline CEEC3 - CAC & & & $(0,0)$ & $(1,10)$ & 0 & $57.945^{* *}$ & $-45.788^{*}$ & $\mathrm{OK}$ \\
\hline & COINT & $-2.705(0)$ & $-2.718(0)$ & -1.295 & 1 & 21.833 & -45.781 & \\
\hline & ECT & 0 & 0 & 0 & 2 & 12.453 & -45.769 & \\
\hline & & & & & 3 & 4.790 & -45.757 & \\
\hline & & & & & 4 & & -45.745 & \\
\hline CEEC3 - UKX€ & & & $(0,0)$ & $(1,10)$ & 0 & $54.259^{* *}$ & $-46.62388^{*}$ & $\mathrm{OK}$ \\
\hline & COINT & $-2.303(0)$ & $-2.321(0)$ & -1.307 & 1 & 21.335 & -46.616 & \\
\hline & ECT & -0.001 & -0.001 & -0.001 & 2 & 8.054 & -46.605 & \\
\hline & & & & & 3 & 1.755 & -46.592 & \\
\hline & & & & & 4 & & -46.579 & \\
\hline CEEC3-CAC & & & & & 0 & & & $\mathrm{NO}$ \\
\hline - DAX- UKX & & & $(0,0)$ & $(1,0)$ & & 76.804 & $-67.887^{*}$ & \\
\hline & COINT & $-4.107(5)$ & $-4.107(5)$ & 0.71 & 1 & 47.842 & -67.884 & \\
\hline & $\mathrm{ECT}$ & $-0.001 * * *$ & $-0.001 * * *$ & $-0.001 * * *$ & 2 & 29.386 & -67.880 & \\
\hline & & & & & 3 & 16.587 & -67.875 & \\
\hline & & & & & 4 & 5.692 & -67.871 & \\
\hline & & & & & 5 & 0.025 & -67.866 & \\
\hline & & & & & 6 & & -67.861 & \\
\hline
\end{tabular}




\subsection{Granger Causality for the Returns Series}

We now turn to the question of whether there is a causal relationship between the stock markets under study. Since the data series turned out to be difference stationary and because we were unable to establish any robust cointegration between them, according to the testing strategy we set out in Figure 1, Granger causality tests performed for data in first differences, e.g. for stock index returns, seem to be the appropriate tool. However, before giving an account of the estimation results, it is useful to take a look at pair wise simple correlation coefficients obtained for the first-differenced data. As reported in Table 6, the correlation coefficients between the three Central European stock indices are fairly low and amount to around 0.2 . The correlation coefficients are slightly higher, in the neighbourhood of 0.3 between the individual CEE markets and the Western European stock markets. Finally, the correlation seems to be particularly strong between the DAX, CAC and UKX stock market indices.

Table 6. Correlations for Stock Returns

\begin{tabular}{|c|c|c|c|c|c|c|}
\hline & BUX & $\begin{array}{l}\text { PX- } \\
0\end{array}$ & WIG20 & DAX & CAC & UKX \\
\hline BUX & 1 & & & & & \\
\hline PX-50 & 0.18 & 1 & & & & \\
\hline WIG20 & 0.17 & 0.15 & 1 & & & \\
\hline DAX & 0.31 & 0.26 & 0.29 & 1 & & \\
\hline CAC & 0.28 & 0.26 & 0.28 & 0.91 & 1 & \\
\hline UKX & 0.27 & 0.24 & 0.24 & 0.78 & 0.80 & 1 \\
\hline
\end{tabular}

Coming now to the Granger causality tests, results for a window corresponding to the size of one day are reported in Table 7 . The numbers across the top of the table refer to ticks 1 through 80 . Here, all 15 possible pairs are tested. It appears that most of the series Grangercause each other at the horizons of up to one day. Put differently, not only stock returns in Frankfurt, London and Paris Granger-cause stock returns in the three CEECs, but the CEECs also influence each other and stock returns in Frankfurt, London and Paris. A notable 
exception is the Polish WIG-20, which is found to be Granger-caused by all the other stock indices. However, returns in the WIG-20 stock index Granger-cause the BUX and PX-50 only at very short horizons, and no causality is running from the WIG-20 to the DAX, CAC and UKX stock market indices. In sum, there is causality across the board up to 40 ticks, the sole exception being WIG20 on the 3 Western indices. While not directly comparable, our results are broadly in line with those of Černý and Koblas (2005) derived for the same set of markets but for a much shorter and earlier period.

Table 7. Granger Causality for Returns

\begin{tabular}{|c|c|c|c|c|c|c|c|c|c|}
\hline & 1 & 10 & 20 & 30 & 40 & 50 & 60 & 70 & 80 \\
\hline PX-50=>BUX & $882.837 * * *$ & $419.672^{* * *}$ & $227.071 * * *$ & $159.67 * * *$ & $124.39 * * *$ & $101.547^{* * *}$ & $87.23 * * *$ & $75.375 * * *$ & $71.689 * * *$ \\
\hline$B U X=>P X-50$ & $268.538 * * *$ & $31.227 * * *$ & $15.782^{* * *}$ & $10.581 * * *$ & $8.158^{* * *}$ & $6.773^{* * *}$ & $6.279 * * *$ & $6.043^{* * *}$ & $6.248^{* * *}$ \\
\hline WIG20 $=>$ BUX & $5.442^{* * *}$ & $2.874 * *$ & $1.948^{*}$ & $1.653^{*}$ & $1.341^{* *}$ & 1.16 & 1.108 & 1.492 & 1.436 \\
\hline $\mathrm{BUX}=>$ WIG 20 & $1081.635^{* * *}$ & $123.639^{* * *}$ & 65.589 *** & $44.542^{* * *}$ & $34.633 * * *$ & $28.912^{* * *}$ & $25.451 * * *$ & $22.799 * * *$ & $26.252^{* * *}$ \\
\hline PX-50=> WIG20 & $2396.279 * * *$ & $703.88^{* * * *}$ & $389.782^{* * *}$ & $274.355^{* * *}$ & $213.951 * * *$ & $174.58^{* * *}$ & $149.658^{* * *}$ & $132.991 * * *$ & $123.152^{* * *}$ \\
\hline $\mathrm{WIG} 20=>\mathrm{PX}-50$ & 0.143 & $3.48^{* * *}$ & $2.042 *$ & 1.479 & $1.378^{* *}$ & $1.272^{* *}$ & 1.387 & 1.354 & 1.294 \\
\hline $\mathrm{DAX}=>\mathrm{BUX}$ & 75.121 *** & $10.412^{* * *}$ & $6.891 * * *$ & $5.685^{* * *}$ & $6.177^{* * *}$ & $5.238^{* * *}$ & $5.123^{* * *}$ & $4.703^{* * *}$ & $4.51^{* * *}$ \\
\hline $\mathrm{BUX}=$ & $817.258^{* * *}$ & $89.966^{* * *}$ & $48.186^{* * *}$ & $33.379 * * *$ & $25.573 * * *$ & $20.975^{* * *}$ & $18.448^{* * *}$ & $16.843^{* * *}$ & $22.076^{* * *}$ \\
\hline $\mathrm{CAC}=>\mathrm{BUX}$ & $22.19^{* * *}$ & $5.64 * * *$ & $5.901^{* * *}$ & $4.458^{* * *}$ & $3.981^{* * *}$ & $4.402^{* * *}$ & $7.551 * * *$ & $6.755^{* * *}$ & $6.237 * * *$ \\
\hline $\mathrm{BUX}=$ & $1269.809^{* * *}$ & 135.059 *** & $70.817^{* * *}$ & $48.38 * * *$ & $36.645^{* * *}$ & $29.933 * * *$ & $26.216^{* * *}$ & $23.358^{* * *}$ & $27.917 * * *$ \\
\hline $\mathrm{UKX}=>\mathrm{BUX}$ & $292.026^{* * *}$ & $31.763 * * *$ & $16.604^{* * *}$ & $10.49^{* * *}$ & $8.183^{* * *}$ & $7.138^{* * *}$ & $6.207 * * *$ & $5.621^{* * *}$ & 5.231 *** \\
\hline$B U X=>U K X$ & $2085.164^{* * *}$ & $212.947^{* * *}$ & $108.48^{* * * *}$ & $73.167 * * *$ & $55.107 * * *$ & $44.486^{* * * *}$ & $37.417 * * *$ & $32.417 * * *$ & $34.071 * * *$ \\
\hline $\mathrm{DAX}=>1$ & $7.317^{* * *}$ & $2.544 * *$ & $2.396^{* *}$ & $2.721^{* * *}$ & $2.601^{* * * *}$ & $2.238^{* * *}$ & $2.223^{* *}$ & $2.193^{* *}$ & $2.756^{* *}$ \\
\hline PX $-50=>$ DAX & $1145.328^{* * *}$ & $724.917^{* * *}$ & $381.476^{* * *}$ & $259.385^{* * *}$ & $202.683^{* * *}$ & $165.788^{* * *}$ & $142.446 * * *$ & $124.599 * * *$ & $120.894 * * *$ \\
\hline $\mathrm{CAC}=>\mathrm{PX}-50$ & $10.651 * * *$ & $5.357^{* * *}$ & $4.065^{* * *}$ & $3.723^{* * *}$ & $3.15^{* * *}$ & $4.531 * * *$ & $6.01 * * *$ & $5.512^{* * *}$ & $4.798^{* * *}$ \\
\hline$P X-50=>C A C$ & $1497.255^{* * *}$ & $729.701 * * *$ & $380.928 * * *$ & $257.832^{* * *}$ & $199.556^{* * *}$ & $164.733^{* * * *}$ & $140.597 * * *$ & $123.718^{* * *}$ & $113.105^{* * *}$ \\
\hline PX-50 & $310.86^{* * *}$ & 29.661 *** & $14.822 * * *$ & $9.867 * * *$ & $7.587^{* * *}$ & $6.107^{* * *}$ & $5.485^{* * *}$ & $5.053^{* * *}$ & $6.09 * * *$ \\
\hline PX-50=>UKX & 2378.739*** & $754.745^{* * *}$ & $391.264^{* * *}$ & $264.294 * * *$ & $202.8^{* * *}$ & $164.685^{* * *}$ & $140.384 * * *$ & $122.773 * * *$ & $118.692 * * *$ \\
\hline WIG20 & $152.589 * * *$ & $22.029 * * *$ & 13.891 *** & $10.401 * * *$ & $9.679 * * *$ & $8.808^{* * *}$ & $8.179 * * *$ & $7.756^{* * *}$ & $9.044^{* * *}$ \\
\hline WIG20 $=>$ DAX & 0.153 & 0.957 & 0.663 & 0.711 & 0.69 & 0.608 & 0.749 & 0.953 & 1.157 \\
\hline $\mathrm{VIG} 20$ & $422 * * *$ & $1.721 * * *$ & $351 * * *$ & $951 * * *$ & $82 * * *$ & $941 * * *$ & $441 * * *$ & $427^{* * *}$ & $548^{* * *}$ \\
\hline WIG20 $=>$ CAC & 0.577 & 0.855 & 0.746 & 0.659 & 0.631 & 0.581 & 0.671 & 0.867 & 1.185 \\
\hline UKX $=>$ WIG20 & $675.518^{* * *}$ & $81.634^{* * *}$ & $43.169^{* * *}$ & $30.35^{* * *}$ & $23.697 * * *$ & $19.864^{* * *}$ & $17.162^{* * *}$ & $15.334^{* * *}$ & $18.687^{* * *}$ \\
\hline$>\mathrm{UKX}$ & 0.123 & 0.703 & 0.517 & 0.53 & 0.56 & 0.534 & 0.55 & 0.614 & 0.892 \\
\hline $\mathrm{CAC}=>\mathrm{DAX}$ & $8.431^{* * *}$ & $2.842^{* *}$ & $2.407^{* *}$ & $2.167^{* *}$ & $2.08^{* * *}$ & $8.487^{* * *}$ & $7.523^{* * *}$ & $6.737 * * *$ & $6.31 * * *$ \\
\hline $\mathrm{DAX}=>\mathrm{CAC}$ & $439.921 * * *$ & $47.681^{* * *}$ & $24.385^{* * *}$ & $17.999 * * *$ & $15.568^{* * *}$ & $12.824 * * *$ & $10.809 * * *$ & $9.452 * * *$ & $8.644 * * *$ \\
\hline $\mathrm{UKX}=>\mathrm{DAX}$ & $219.351 * * *$ & $24.66^{* * *}$ & $13.374^{* * *}$ & $9.352^{* * *}$ & $7.689^{* * *}$ & $6.467 * * *$ & $6.81^{* * *}$ & $6.448^{* * *}$ & $7.401 * * *$ \\
\hline $\mathrm{DAX}=>\mathrm{UKX}$ & $185.709 * * *$ & $21.03 * * *$ & $11.573^{* * *}$ & $8.064 * * *$ & $7.847 * * *$ & $6.438 * * *$ & $5.54^{* * *}$ & $4.816^{* * *}$ & $4.625^{* * *}$ \\
\hline $\mathrm{UKX}=>$ & $621.936 * * *$ & $65.875^{* * *}$ & $34.351 * * *$ & $23.422 * * *$ & $18.15^{* * *}$ & $14.965^{* * *}$ & $13.667 * * *$ & $12.304^{* * *}$ & $12.57 * * *$ \\
\hline $\mathrm{CAC}=>\mathrm{UKX}$ & $99.327 * * *$ & $11.906^{* * *}$ & $7.664^{* * *}$ & $5.721 * * *$ & $4.668 * * *$ & $8.03^{* * *}$ & $6.992 * * *$ & $6.249 * * *$ & $6.68 * * *$ \\
\hline
\end{tabular}

\subsection{Granger Causality for the Volatility Series}

The first necessary step to make when investigating volatility spillovers across countries is to estimate a univariate GARCH model, from which we can extract the estimated volatility of the individual stock markets. Research examining high-frequency financial data has suggested that volatility dynamics may be confounded by the existence of both a periodic pattern and long-memory volatility. Thus, we derived volatility from the component GARCH model 
(CGARCH) as our volatility series for the Granger causality analysis. ${ }^{7}$ The results can be found in Table A1 in the appendix.

Having done this, we need to find out the degree of integration of the estimated volatility series in order to adhere to our testing strategy and to remain consistent with earlier parts of the paper. According to Tables $8 \mathrm{a}$ and $8 \mathrm{~b}$, the ADF and PP unit root test can reject the null of a unit root both for data in levels and in first differences. The KPSS tests cannot reject the null of stationarity for the same setting. This leads us to conclude that all series are I(0) processes. In accordance with Figure 1, this implies that the Granger causality tests should be applied to the GARCH series in level.

Table 8a. Table Unit Root Tests for GARCH series, levels

\begin{tabular}{|c|c|c|c|c|c|c|c|c|}
\hline & $\mathrm{ADF}$ & & \multicolumn{2}{|l|}{$\mathrm{PP}$} & KPSS & \multicolumn{2}{|c|}{ ERS } & \\
\hline & Trend & constant & trend & constant & \multicolumn{4}{|c|}{ Trend constant trend constant } \\
\hline \multicolumn{9}{|c|}{ CGARCH } \\
\hline BUX & $-99.09 * * *$ & $-99.09 * * *$ & $-135.16^{* * *}$ & $-135.16^{* * *}$ & 0.209 & 0.238 & 0.01 & 0 \\
\hline PX-50 & $-60.6^{* * *}$ & $-60.57 * * *$ & $-143.69 * * *$ & $-143.81 * * *$ & 0.228 & 0.619 & 0.01 & 0 \\
\hline WIG20 & $-60.39 * * *$ & $-60.2^{* * *}$ & $-132.93^{* * *}$ & $-132.64 * * *$ & 0.609 & 4.865 & 0.01 & 0 \\
\hline DAX & $-95.26^{* * *}$ & $-81.61 * * *$ & $-127.1 * * *$ & $-127.45^{* * *}$ & 0.122 & 2.702 & 0.01 & 0 \\
\hline $\mathrm{CAC}$ & $-65.42^{* * *}$ & $-65.21 * * *$ & $-129.63^{* * *}$ & $-130.25^{* * *}$ & 0.119 & 2.142 & 0 & 0 \\
\hline UKX & $-83.26 * * *$ & $-83.2 * * *$ & $-133.19 * * *$ & $-134.13^{* * *}$ & 0.11 & 0.847 & 0.01 & 0 \\
\hline
\end{tabular}

Table 8b. Unit Root Tests for GARCH series, first differences

\begin{tabular}{|c|c|c|c|c|c|c|c|}
\hline & $\mathrm{ADF}$ & \multicolumn{3}{|c|}{$\mathrm{PP}$} & \multicolumn{3}{|l|}{ KPSS } \\
\hline & Trend & constant & Trend & constant & trend & constant trend & constant \\
\hline \multicolumn{8}{|c|}{ CGARCH } \\
\hline BUX & $-43.56 * * *$ & $-43.56 * * *$ & $-5670.32 * * *$ & $-5670.3^{* * *}$ & 0.032 & 0.032571 .29 & 153.71 \\
\hline PX-50 & $-43.93 * * *$ & $-43.93^{* * *}$ & $-6685.52 * * *$ & $-6686.19 * * *$ & 0.055 & 0.056280 .71 & 75.48 \\
\hline WIG20 & $-40.38 * * *$ & $-40.38 * * *$ & $-4032.91 * * *$ & $-4032.57 * * *$ & 0.022 & 0.023408 .58 & 109.86 \\
\hline DAX & $-41.15^{* * *}$ & $-41.15^{* * *}$ & $-7992.72 * * *$ & $-7990.33 * * *$ & 0.046 & 0.048590 .04 & 159.99 \\
\hline CAC & $-41.57 * * *$ & $-41.57 * * *$ & $-7077.84 * * *$ & $-7076.19 * * *$ & 0.098 & 0.112865 .28 & 252.29 \\
\hline UKX & $-41.31 * * *$ & $-41.31 * * *$ & $-9756.64 * * *$ & $-9756.77 * * *$ & 0.12 & $0.12 \quad 684.9$ & 184.27 \\
\hline
\end{tabular}

However, prior to tackling this issue, let us briefly consider the correlation coefficients for the estimated GARCH series presented in Table 9. Notwithstanding the fact that the size

\footnotetext{
${ }^{7}$ McMillan and Speight (2002) analyze five-minute sampled UK short sterling bond futures and provide evidence for both a U-shaped intraday pattern and long-run dependence in volatility. Estimation of a component-
} 
of the correlation coefficient depends upon the specific form of the GARCH models based on which the volatility series are derived, it is fair to say that the overall picture resembles the one obtained for the stock returns. This means, more specifically, that volatility among the three Western European stock indices tends to be correlated most and that the correlation coefficient is lower, but is still around 0.5 between the Western European stock market indices and those of the three CEECs. Lastly, the correlation within the group of CEECs is found, with some exceptions, to be systematically the lowest.

Table 9. Correlations for Stock Market (GARCH) Volatility

\begin{tabular}{|c|cccccc|}
\hline & \multicolumn{2}{|c|}{ CGARCH } & & & & \\
& BUX & PX-50 & WIG20 & DAX & CAC & UKX \\
\hline BUX & 1 & & & & & \\
PX-50 & 0.27 & 1 & & & & \\
WIG20 & 0.25 & 0.88 & 1 & & & \\
DAX & 0.41 & 0.30 & 0.34 & 1 & & \\
CAC & 0.43 & 0.28 & 0.31 & 0.92 & 1 & \\
UKX & 0.67 & 0.26 & 0.28 & 0.66 & 0.68 & 1 \\
\hline
\end{tabular}

Now, coming to the issue of Granger causality, the test results provide convincing evidence in favour of bidirectional Granger causality going on between the volatility of the stock markets under consideration (see Table 10). All 15 possible pairs are tested. In other words, changes in volatility for instance in the BUX tend to induce changes in volatility of the PX-50 and WIG-20, and vice versa. All the same, volatility changes in Western European stock markets seem to affect volatility in Eastern Europe, which also holds true the other way around. To conclude, the CGARCH-based estimation results provide very strong support for the existence of bidirectional causal relationships for volatility in the whole set of stock market indices.

GARCH model confirms the presence of both long-run and short-run volatility dynamics. Their results suggest that taking both components into account improves the accuracy of volatility forecasts. 
Table 10. Granger Causality for GARCH series - CGARCH

\begin{tabular}{|c|c|c|c|c|c|c|c|c|c|}
\hline CGARCH & 1 & 10 & 20 & 30 & 40 & 50 & 60 & 70 & 80 \\
\hline $\mathrm{PX}-50=>\mathrm{BUX}$ & 3149.782 *** & $322.512^{* * *}$ & $162.287^{* * *}$ & $108.675^{* * *}$ & $81.66^{* * *}$ & $65.875^{* * *}$ & $54.915^{* * *}$ & $46.307 * * *$ & $36.997 * * *$ \\
\hline$B U X=>P X-50$ & $41.206 * * *$ & $7.227 * * *$ & $4.184 * * *$ & $3.159 * * *$ & $2.629 * * *$ & $2.287 * * *$ & $2.029 *$ & $38.436 * * *$ & $24.536 * * *$ \\
\hline WIG20=> BUX & $3212.164^{* * *}$ & $332.229 * * *$ & $166.17 * * *$ & $110.895^{* * *}$ & $83.202^{* * *}$ & $67.168^{* * *}$ & $56.043^{* * *}$ & $47.022 * * *$ & $35.244 * * *$ \\
\hline BUX $=>$ WIG20 & $152.102 * * *$ & $3.737 * * *$ & $1.926^{*}$ & 1285 & 0.98 & 0.811 & 0.726 & $37.483^{* * *}$ & $16.22^{* * *}$ \\
\hline PX-50=> WIG20 & $399.663^{* * *}$ & $30.089 * * *$ & $15.318^{* * *}$ & $10.511 * * *$ & $8.271 * * *$ & 7.037 *** & $6.808^{* * *}$ & $11.372^{* * *}$ & $28.699 * * *$ \\
\hline WIG $20=>$ PX -50 & $265.862 * * *$ & $42.252^{* * *}$ & $23.276^{* * *}$ & $17.374 * * *$ & $14.84^{* * *}$ & $13.486^{* * *}$ & $12.541 * * *$ & $17.929 * * *$ & $50.857 * * *$ \\
\hline $\mathrm{DAX}=>\mathrm{BUX}$ & $128.072^{\text {*** }}$ & $15.327^{* * *}$ & $7.758^{* * *}$ & $5.343^{* * *}$ & $4.16^{* * *}$ & $3.442^{* * *}$ & $2.989 * * *$ & $2.793^{* *}$ & $6.046^{* * *}$ \\
\hline$B U X=>D A X$ & $6.052^{* * *}$ & $2.466 * *$ & 1.4 & 1002 & 0.833 & 0.727 & 0.643 & 1.75 & $5.145^{* * *}$ \\
\hline $\mathrm{CAC}=>\mathrm{BUX}$ & $90.557 * * *$ & $21.036^{* * *}$ & $10.622^{* * *}$ & $7.211 * * *$ & $5.539 * * *$ & $4.54 * * *$ & 3.887 *** & $3.149^{* * *}$ & $7.627 * * *$ \\
\hline $\mathrm{BUX}=>\mathrm{CAC}$ & $6.121 * * *$ & $5.424 * * *$ & $2.911 * *$ & $2.019 * *$ & $1.576^{* * *}$ & $1.309 * *$ & 1117 & $2.793 * *$ & $4.232 * * *$ \\
\hline $\mathrm{UKX}=>\mathrm{BUX}$ & $10.346^{* * *}$ & $4.072^{* * *}$ & $2.147^{*}$ & $1.587^{*}$ & $1.32^{* *}$ & 1184 & 1.08 & 1.04 & 1224 \\
\hline $\mathrm{BUX}=>\mathrm{UKX}$ & 0.013 & $3.928 * * *$ & $2.019 *$ & 1.37 & 1057 & 0.945 & 0.809 & 1095 & $4.686 * * *$ \\
\hline $\mathrm{DAX}=>\mathrm{PX}-50$ & $473.225^{* * *}$ & $49.763^{* * *}$ & $26.342^{* * *}$ & $18.319^{* * *}$ & $14.152^{* * *}$ & $11.62^{* * *}$ & $10.001^{* * *}$ & $95.551 * * *$ & $15.035^{* * *}$ \\
\hline PX $-50=>$ DAX & $5602.373^{* * *}$ & $617.15^{* * *}$ & $310.398^{* * *}$ & $207.356^{* * *}$ & $155.458^{* * *}$ & $124.514^{* * *}$ & $103.822 * * *$ & $92.679 * * *$ & $71.014 * * *$ \\
\hline $\mathrm{CAC}=>\mathrm{PX}-50$ & 800.467 *** & $139.21^{* * *}$ & $70.177^{* * *}$ & $47.009 * * *$ & $35.49^{* * *}$ & $28.564^{* * *}$ & $23.953^{* * *}$ & $140.201^{* * *}$ & $13.987^{* * *}$ \\
\hline $\mathrm{PX}-50=>\mathrm{CAC}$ & 7517.9 *** & $852.803^{* * *}$ & $427.43^{* * *}$ & $285.276^{* * *}$ & $213.838^{* * *}$ & $171.117^{* * * *}$ & $142.58^{* * *}$ & $141.939 * * *$ & $100.283^{* * *}$ \\
\hline $\mathrm{UKX}=>\mathrm{PX}-50$ & $107.227^{* * *}$ & $11.622^{* * *}$ & $6.794 * * *$ & $5.104 * * *$ & $4.191 * * *$ & $3.651 * * *$ & $3.303^{* * *}$ & $61.398^{* * * *}$ & $18.837 * * *$ \\
\hline $\mathrm{PX}-50=>\mathrm{UKX}$ & $4678.402^{* * *}$ & $484.637^{* * * *}$ & $243.754 * * *$ & $163.032^{* * *}$ & $122.429 * * *$ & $98.645^{* * *}$ & $82.29 * * *$ & 70.281 *** & $58.804 * * *$ \\
\hline $\mathrm{DAX}=>$ WIG20 & $710.05^{* * *}$ & $49.977^{* * * *}$ & $25.073^{* * *}$ & $16.611 * * *$ & $12.418^{* * *}$ & $9.968^{* * *}$ & $8.626^{* * *}$ & $93.325^{* * *}$ & $21.649 * * *$ \\
\hline WIG20 $=>$ DAX & $5377.381 * * *$ & $624.643^{* * *}$ & $313.009^{* * *}$ & $208.837^{* * *}$ & $156.656^{* * *}$ & $125.633^{* * * *}$ & $104.831^{* * *}$ & $92.289 * * *$ & $67.158^{* * *}$ \\
\hline $\mathrm{CAC}=>\mathrm{WIG} 20$ & $1222.107 * * *$ & $138.032^{* * *}$ & $69.476^{* * *}$ & $46.214^{* * *}$ & $34.698^{* * *}$ & $27.838^{* * *}$ & $23.412^{* * *}$ & $142.148^{* * *}$ & $20.712^{* * *}$ \\
\hline WIG20 $=>$ CAC & $7480.153^{* * *}$ & $887.74^{* * *}$ & $444.153^{* * *}$ & $296.124 * * *$ & $221.902^{* * *}$ & $177.528^{* * *}$ & $148.066^{* * *}$ & $144.094 * * *$ & $99.263^{* * *}$ \\
\hline $\mathrm{UKX}=>\mathrm{WIG} 20$ & $296.744^{* * *}$ & $21.439 * * *$ & $10.656^{* * *}$ & $7.064 * * *$ & $5.28 * * *$ & $4.298^{* * *}$ & $3.837 * * *$ & $61.643^{* * *}$ & $29.547 * * *$ \\
\hline WIG20 $=>$ UKX & 4619.939*** & $496.234^{* * *}$ & $248.547 * * *$ & $165.865^{* * *}$ & $124.465^{* * *}$ & $100.377^{* * *}$ & $83.744 * * *$ & $71.475^{* * *}$ & $58.68^{* * *}$ \\
\hline $\mathrm{CAC}=>\mathrm{DAX}$ & $26.255^{* * *}$ & $87.732^{* * *}$ & $43.93 * * *$ & $29.149 * * *$ & $21.736^{* * *}$ & $17.355^{* * *}$ & $14.435^{* * *}$ & $11.71 * * *$ & $10.463^{* * *}$ \\
\hline $\mathrm{DAX}=>\mathrm{CAC}$ & 79.447 *** & $89.34 * * *$ & $44.732^{* * * *}$ & $29.749 * * *$ & $22.255^{* * * *}$ & $17.823^{* * *}$ & $14.843^{* * *}$ & $13.712^{* * * *}$ & $10.748^{* * *}$ \\
\hline $\mathrm{UKX}=>\mathrm{DAX}$ & $19.588 * * *$ & $4.382^{* * *}$ & $2.291 * *$ & $1.579 *$ & $1.232 *$ & 1038 & 0.917 & 1 & 1336 \\
\hline $\mathrm{DAX}=>\mathrm{UKX}$ & $166.352^{* * *}$ & $17.454^{* * *}$ & $8.784^{* * *}$ & $5.942^{* * *}$ & $4.554 * * *$ & $3.711^{* * *}$ & $3.17 * * *$ & $3.35^{* * *}$ & $10.807^{* * *}$ \\
\hline $\mathrm{UKX}=>\mathrm{CAC}$ & $11.541 * * *$ & $28.799 * * *$ & $14.499 * * *$ & $9.685^{* * *}$ & 7.269 *** & $5.857 * * *$ & $4.907 * * *$ & $4.675^{* * *}$ & $4.388^{* * *}$ \\
\hline $\mathrm{CAC}=>\mathrm{UKX}$ & $79.608^{* * *}$ & $31.891^{* * *}$ & $15.989 * * *$ & $10.699 * * *$ & $8.068^{* * *}$ & $6.524^{* * *}$ & $5.49 * * *$ & $4.694 * * *$ & $13.149 * * *$ \\
\hline
\end{tabular}

\subsection{VAR Estimations}

The VAR framework described in Section 4 allows us to analyse the following four features:

1.) spillovers from stock returns to stock returns

2.) spillovers from volatility to stock returns

3.) spillovers from volatility to volatility

4.) spillovers from stock returns to volatility

As Tables 11a to $11 \mathrm{~d}$ indicate, past values of the return series of the BUX and PX-50 have a positive impact on the WIG20 returns, but only the WIG20 has a negative influence on the BUX. The BUX intraday returns also impact on positively on PX-50. At the same time, both the DAX and CAC are found to impact positively on all three CEEC indices, although this result is sensitive to the specific VAR configuration. The UKX seems to have a positive effect 
only on the Hungarian and Polish stock market index. The effect of stock market volatility on stock returns is fairly limited among the CEECs, given that only stock volatility in the PX-50 positively influences stock returns in Budapest and Warsaw. By contrast, an increase in stock volatility on the Paris and Frankfurt stock exchanges tend to generate a short-term increase in returns in all three CEE stock markets. At the same time, volatility in the UKX tends to impact only returns of the WIG20.

Turning now to the influence of developments on other markets on stock market volatility, the estimation results indicate that changes in volatility in any of the three CEECs positively affect volatility in the two others. But the PX-50 is also found to have a negative influence on the WIG20, the BUX on the PX-50 and the WIG on the BUX at higher lag lengths. This is an important finding, since most of the earlier research concludes that spillover effects are significant only from the dominant market to the smaller market and that the volatility spillover effects are unidirectional (Janakiramanan and Lamba, 1998; Hamao, Masulis and Ng, 1990). Our results are in line with those of Bala and Premarante (2003), who bring evidence that it is plausible for volatility to spillover from the smaller market to the dominant market. $^{8}$

In addition to this, an increase in the volatility of any of the three Western European stock indices yields an increase in volatility in the PX-50 and the WIG20, whereas the BUX remains unaffected. Finally, we can observe that from the return series only three return series have a positive impact on one single volatility series. To be more precise, the PX-50, DAX and CAC returns exhibit a short-term positive relationship with the BUX volatility series.

\footnotetext{
${ }^{8}$ Results of Bala and Premarante (2003) support small but significant volatility spillover from Singapore into Hong Kong, Japan and US markets despite the latter three being dominant markets.
} 
Table 11a. VAR mean - variance, CGARCH, DAX

\begin{tabular}{|c|c|c|c|c|c|c|c|c|}
\hline & BUX & PX-50 & WIG20 & DAX & BUX_CG & PX-50_CG & WIG20_CG & DAX_CG \\
\hline BUX(-1) & 0.001 & 0.004 & 0.011 & 0.008 & $-0.00010^{* * *}$ & $-0.00004^{*}$ & $-0.00015^{* * *}$ & $-0.00009 * * *$ \\
\hline BUX $(-2)$ & $0.011 *$ & 0.006 & $0.024 * * *$ & 0.001 & -0.00001 & 0.00001 & 0.00004 & 0.00000 \\
\hline PX50(-1) & 0.004 & $0.078^{* * *}$ & 0.016 & -0.002 & $-0.00010^{* * *}$ & $-0.00042^{* * *}$ & $-0.00016^{* * *}$ & $-0.00012^{* * *}$ \\
\hline PX50(-2) & 0.002 & $0.030 * * *$ & $0.021 * *$ & $0.016^{*}$ & $0.00003^{* * *}$ & $0.00008^{* * *}$ & 0.00000 & $0.00004 * * *$ \\
\hline WIG20(-1) & 0.006 & -0.001 & $-0.046^{* * *}$ & -0.001 & $-0.00002 * * *$ & 0.00001 & 0.00003 & $-0.00003^{* * *}$ \\
\hline WIG20(-2) & 0.007 & 0.000 & $-0.062 * * *$ & 0.003 & 0.00001 & -0.00001 & -0.00001 & $0.00001^{* *}$ \\
\hline $\operatorname{DAX}(-1)$ & $0.017^{* * *}$ & 0.005 & $0.066^{* * *}$ & $-0.011 *$ & $-0.00001^{* *}$ & $0.00004 *$ & -0.00005 & $-0.00008^{* * *}$ \\
\hline $\operatorname{DAX}(-2)$ & 0.010 & 0.005 & $0.033^{* * *}$ & 0.001 & $0.00001^{* *}$ & -0.00001 & -0.00004 & 0.00000 \\
\hline BUX_CG (-1) & -1208558.0 & -3012243.0 & $-3779668.0^{* * *}$ & -5542985.0 & $0.175^{* * *}$ & $-0.052 * *$ & 0.042 & $-0.059 * * *$ \\
\hline BUX_CG (-2) & 0.182 & -3459936.0 & -1050633.0 & -6659434.0 & $0.043 * * *$ & $0.048^{* * *}$ & $0.107 * * *$ & $-0.012 * *$ \\
\hline PX50_CG (-1) & $1345904.0^{* * *}$ & 0.090 & $1623622.0^{* *}$ & $1151380.0^{* *}$ & 0.057 *** & $0.283^{* * *}$ & $-0.329 * * *$ & $0.088^{* * *}$ \\
\hline PX50_CG (-2) & -6337057.0 & -2867714.0 & $-1087980.0^{*}$ & $-1101707.0 * *$ & 0.006 & $-0.086 * * *$ & $-0.250 * * *$ & -0.003 \\
\hline WIG20_CG (-1) & $-1204063.0^{* * *}$ & -2572261.0 & $-1346597.0 * * *$ & $-1001620.0^{* *}$ & $0.039 * * *$ & $-0.117 * * *$ & $0.377^{* * *}$ & $0.042^{* * *}$ \\
\hline WIG20_CG (-2) & 2987598.0 & 0.436 & 5020729.0 & $6257860.0^{*}$ & $-0.014 * * *$ & $0.027 * *$ & $0.200^{* * *}$ & $-0.023 * * *$ \\
\hline DAX_CG (-1) & $1935113.0^{* * *}$ & $1009936.0 * *$ & $3267547.0^{* * *}$ & $1477470.0^{* *}$ & -0.004 & $0.465 * * *$ & $0.630 * * *$ & $0.227 * * *$ \\
\hline DAX_CG (-2) & 6775138.0 & 2562420.0 & -2912404.0 & 5416895.0 & 0.008 & $0.134 * * *$ & $0.176^{* * *}$ & $0.046^{* * *}$ \\
\hline $\mathrm{C}$ & $0.00002^{* *}$ & $0.00002^{* * *}$ & $0.00003^{* *}$ & 0.00001 & $0.00000^{* * *}$ & $0.00000^{* * *}$ & $0.00000^{* * *}$ & $0.00000 * * *$ \\
\hline $\mathrm{R} 2$ & 0.002 & 0.009 & 0.010 & 0.001 & 0.237 & 0.060 & 0.127 & 0.289 \\
\hline R2 ADJ & 0.001 & 0.008 & 0.009 & 0.000 & 0.237 & 0.060 & 0.126 & 0.289 \\
\hline
\end{tabular}

Table 11b. VAR mean - variance, CGARCH, CAC

\begin{tabular}{|c|c|c|c|c|c|c|c|c|}
\hline & BUX & PX-50 & WIG20 & CAC & BUX_CG & PX-50_CG & WIG20_CG & CAC_CG \\
\hline BUX(-1) & 0.002 & 0.005 & $0.015^{*}$ & 0.008 & $-0.00010^{* * *}$ & -0.00003 & $-0.00014 * * *$ & $-0.00005^{* * *}$ \\
\hline BUX $(-2)$ & $0.011 *$ & 0.006 & $0.025^{* * *}$ & 0.000 & -0.00001 & 0.00002 & 0.00005 & 0.00000 \\
\hline PX50(-1) & 0.004 & $0.079 * * *$ & $0.019 *$ & -0.009 & $-0.00010^{* * *}$ & $-0.00041 * * *$ & $-0.00016^{* * *}$ & $-0.00008^{* * *}$ \\
\hline PX50(-2) & 0.003 & $0.030^{* * *}$ & $0.021 * *$ & 0.008 & $0.00003^{* * *}$ & $0.00009^{* * *}$ & 0.00002 & $0.00003 * * *$ \\
\hline WIG20(-1) & 0.007 & -0.001 & $-0.044 * * *$ & 0.001 & $-0.00003^{* * *}$ & 0.00002 & 0.00003 & $-0.00001 * * *$ \\
\hline WIG20(-2) & 0.007 & 0.000 & $-0.062 * * *$ & 0.002 & 0.00001 & -0.00002 & -0.00001 & 0.00001 \\
\hline $\operatorname{DAX}(-1)$ & $0.017 * *$ & 0.001 & $0.067^{* * *}$ & -0.002 & 0.00000 & 0.00001 & $-0.00006^{*}$ & $-0.00004^{* * *}$ \\
\hline $\operatorname{DAX}(-2)$ & 0.010 & 0.006 & $0.040^{* * *}$ & 0.003 & $0.00001^{* *}$ & -0.00001 & -0.00005 & 0.00001 \\
\hline BUX_CG (-1) & $-1417522.0^{*}$ & -3771805.0 & $-3669418.0^{* * * *}$ & 4472275.0 & $0.172^{* * *}$ & $-0.132^{* * *}$ & $-0.072^{* *}$ & $-0.042^{* * *}$ \\
\hline BUX_CG (-2) & 4845332.000 & -1840459.0 & 0.1 & -3870938.0 & $0.045^{* * *}$ & $0.164 * * *$ & $0.273^{* * *}$ & 0.002 \\
\hline PX50_CG (-1) & $1271044.0^{* *}$ & -0.096 & $1605520.0^{* *}$ & $9277856.0^{* *}$ & $0.058^{* * *}$ & $0.273 * * *$ & $-0.341 * * *$ & $0.059 * * *$ \\
\hline PX50_CG (-2) & -6360937.0 & -3121167.0 & $-1054743.0^{*}$ & -6881149.0 & 0.004 & $-0.106^{* * *}$ & $-0.279 * * *$ & $-0.011 * * *$ \\
\hline WIG20_CG (-1) & $-1113025.0^{* * *}$ & -2307545.0 & $-1266672.0^{* * *}$ & $-7930639.0 * *$ & $0.038 * * *$ & $-0.106 * * *$ & $0.392 * * *$ & $0.039 * * *$ \\
\hline WIG20_CG (-2) & 2770027.0 & 0.335 & 4922432.0 & 3665288.0 & $-0.014^{* * *}$ & $0.024 * *$ & $0.196 * * *$ & $-0.023 * * *$ \\
\hline DAX_CG (-1) & $3747388.0^{* * *}$ & $1904952.0^{* * *}$ & $4478607.0^{* * *}$ & $2526831.0 * * *$ & 0.007 & $1043761.000^{* * *}$ & $1428099.000^{* * *}$ & $0.227 * * *$ \\
\hline DAX_CG $(-2)$ & -7483176.0 & -1439840.0 & -1020426.0 & -9365013.0 & 0.007 & $-0.176^{* * *}$ & $-0.276 * * *$ & $0.050 * * *$ \\
\hline $\mathrm{C}$ & 0.00001 & 0.00001 & 0.00001 & 0.00000 & $0.00000^{* * *}$ & $0.00000^{* * *}$ & 0.00000 & $0.00000^{* * *}$ \\
\hline $\mathrm{R} 2$ & 0.002 & 0.009 & 0.009 & 0.001 & 0.237 & 0.077 & 0.143 & 0.324 \\
\hline R2 ADJ & 0.001 & 0.008 & 0.008 & 0.000 & 0.237 & 0.077 & 0.143 & 0.323 \\
\hline
\end{tabular}

Table 11c. VAR mean - variance, CGARCH, UKX

\begin{tabular}{|c|c|c|c|c|c|c|c|c|}
\hline & BUX & PX-50 & WIG20 & UKX & BUX_CG & PX-50_CG & WIG20_CG & UKX_CG \\
\hline BUX $(-1)$ & 0.003 & 0.004 & $0.019 * *$ & 0.005 & $-0.00010^{* * *}$ & -0.00002 & $-0.00013 * * *$ & $-0.00002^{* * *}$ \\
\hline BUX(-2) & $0.014 * *$ & $0.008^{*}$ & $0.023^{* * *}$ & -0.003 & -0.000003 & 0.000002 & 0.00002 & 0.000002 \\
\hline PX50(-1) & 0.004 & $0.078 * * *$ & $0.026 * *$ & -0.006 & $-0.00010^{* * *}$ & $-0.00042 * * *$ & $-0.00015^{* * *}$ & $-0.00003^{* * *}$ \\
\hline PX50(-2) & 0.005 & $0.031^{* * *}$ & $0.019 *$ & 0.003 & $0.00004^{* * *}$ & 0.00005 & -0.00004 & $0.00001^{* * *}$ \\
\hline WIG20(-1) & 0.007 & -0.002 & $-0.041 * * *$ & 0.000 & $-0.00002 * * *$ & 0.00001 & 0.00004 & $-0.00001^{* * *}$ \\
\hline WIG20(-2) & $0.008^{*}$ & 0.000 & $-0.063 * * *$ & 0.000 & $0.00001 * *$ & -0.00002 & -0.00003 & $0.00000 * *$ \\
\hline DAX $(-1)$ & $0.033^{* * *}$ & 0.007 & $0.054 * * *$ & 0.008 & $-0.00002^{*}$ & 0.00002 & $-0.00015^{* * *}$ & $-0.00007 * * *$ \\
\hline $\operatorname{DAX}(-2)$ & -0.003 & 0.005 & $0.065^{* * *}$ & $0.021 * * *$ & 0.00001 & -0.00001 & -0.00005 & -0.000001 \\
\hline BUX_CG (-1) & -6288329.0 & -1575265.0 & $-3446122.0^{* * *}$ & -2205275.0 & $0.177 * * *$ & $0.075^{* * *}$ & $0.213^{* * *}$ & $-0.020^{* * *}$ \\
\hline BUX_CG (-2) & 1571345.000 & -5457413.0 & -4383829.0 & -1121269.0 & $0.041 * * *$ & $-0.068 * * *$ & -0.047 & $-0.009 * * *$ \\
\hline PX50_CG (-1) & $1259463.0^{* *}$ & -0.228 & $1515399.0^{* *}$ & 5172261.0 & $0.056 * * *$ & $0.260 * * *$ & $-0.359 * * *$ & $0.032 * * *$ \\
\hline PX50_CG (-2) & -4124562.0 & -2017257.0 & -9603499.0 & -4542731.0 & 0.006 & $-0.037^{* *}$ & -0.181 *** & $0.004^{* *}$ \\
\hline WIG20_CG (-1) & $-1078288.0^{* * *}$ & -1859436.0 & $-1216775.0^{* * *}$ & $-4086102.0^{*}$ & $0.038^{* * *}$ & $-0.082^{* * *}$ & $0.425^{* * *}$ & $0.018^{* * *}$ \\
\hline WIG20_CG (-2) & 3033185.0 & 0.058 & 3979789.0 & 3109070.0 & $-0.013 * * *$ & 0.012 & $0.179 * * *$ & $-0.009 * * *$ \\
\hline DAX_CG (-1) & 1370581.0 & 2019494.0 & $6585467.0^{* * *}$ & 6320721.0 & -0.024 & $0.567^{* * *}$ & $0.742^{* * *}$ & $0.208^{* * *}$ \\
\hline DAX_CG (-2) & -5002394.0 & 8411202.0 & 1348676.0 & 1457632.0 & 0.020 & $0.363^{* * *}$ & $0.479 * * *$ & $0.057^{* * *}$ \\
\hline & $0.00004^{* * *}$ & $0.00002^{* * *}$ & $0.00004^{* * *}$ & $0.00001 *$ & $0.00000^{* * *}$ & $0.00000^{* * *}$ & $0.00000^{* * *}$ & $0.00000^{* * *}$ \\
\hline $\mathrm{R} 2$ & 0.002 & 0.008 & 0.008 & 0.001 & 0.234 & 0.047 & 0.115 & 0.355 \\
\hline R2 ADJ & 0.001 & 0.008 & 0.007 & 0.000 & 0.233 & 0.047 & 0.115 & 0.354 \\
\hline
\end{tabular}


Table 11d. VAR mean - variance, CGARCH, CEEC3, DAX, CAC and UKX

\begin{tabular}{|c|c|c|c|c|c|c|}
\hline & BUX & PX50 & WIG20 & BUX_CG & PX50_CG & WIG20_CG \\
\hline BUX $(-1)$ & 0.00278 & 0.00347 & $0.01572 *$ & $-0.00010^{* * *}$ & -0.00001 & $-0.00010^{* * *}$ \\
\hline BUX (-2) & $0.01285^{* *}$ & 0.00809* & $0.02318^{* * *}$ & 0.00000 & 0.00002 & 0.00004 \\
\hline BUX $(-3)$ & 0.00265 & $0.01118^{* *}$ & $0.01962 * *$ & 0.00000 & 0.00002 & 0.00001 \\
\hline PX50(-1) & 0.00165 & $0.07814^{* * *}$ & 0.01521 & $-0.00010^{* * *}$ & $-0.00044 * * *$ & $-0.00017^{* * *}$ \\
\hline PX50(-2) & 0.00197 & $0.02968^{* * *}$ & 0.01723 & $0.00004^{* * *}$ & $0.00010^{* * *}$ & 0.00003 \\
\hline PX50(-3) & 0.00047 & $0.01324 * *$ & 0.00910 & 0.00000 & -0.00002 & $-0.00009 * *$ \\
\hline WIG20(-1) & 0.00705 & -0.00260 & $-0.05059^{* * *}$ & $-0.00002^{* * *}$ & 0.00002 & 0.00000 \\
\hline WIG20(-2) & 0.00628 & -0.00078 & $-0.06488 * * *$ & 0.00001 & $-0.00004^{* *}$ & $-0.00004 *$ \\
\hline WIG20(-3) & $0.01039 * *$ & -0.00083 & $-0.01738^{* * *}$ & -0.00001 & $0.00003^{*}$ & 0.00003 \\
\hline $\operatorname{DAX}(-1)$ & $0.02540^{*}$ & $0.02072^{* *}$ & $0.09028^{* * *}$ & $-0.00005^{* * *}$ & $0.00012^{* * *}$ & -0.00002 \\
\hline $\operatorname{DAX}(-2)$ & 0.01514 & 0.00397 & 0.00853 & 0.00000 & -0.00006 & -0.00007 \\
\hline $\operatorname{DAX}(-3)$ & 0.00558 & 0.01022 & -0.01251 & -0.00001 & 0.00007 & 0.00006 \\
\hline $\mathrm{CAC}(-1)$ & -0.02447 & $-0.02607^{* *}$ & 0.00526 & $0.00005^{* * *}$ & $-0.00016 * * *$ & -0.00001 \\
\hline $\mathrm{CAC}(-2)$ & 0.00485 & 0.00416 & 0.00596 & 0.00001 & -0.00006 & $-0.00013^{*}$ \\
\hline CAC $(-3)$ & 0.00883 & -0.00994 & 0.01556 & 0.00001 & -0.00008 & -0.00005 \\
\hline $\mathrm{UKX}(-1)$ & $0.02910^{*}$ & 0.00800 & $-0.05329 * * *$ & -0.00001 & 0.00003 & -0.00008 \\
\hline UKX(-2) & $-0.02710^{*}$ & -0.00542 & $0.05044 * *$ & -0.00002 & 0.00007 & 0.00010 \\
\hline UKX(-3) & -0.01647 & -0.00044 & $0.04457^{* *}$ & 0.00001 & 0.00001 & 0.00001 \\
\hline BUX_CG (-1) & $\mid-7.72938$ & -2.11597 & $-39.43481 * * *$ & $0.17425^{* * *}$ & -0.00222 & $0.10926^{* * *}$ \\
\hline BUX_CG (-2) & 3.09005 & -1.48101 & -9.92950 & $0.04152^{* * *}$ & -0.00213 & 0.03074 \\
\hline BUX_CG (-3) & -2.88557 & -6.399 & 9.446 & 0.00471 & $-0.11415^{* * *}$ & $-0.11630 * * *$ \\
\hline PX50_CG (-1) & 8.28799 & -0.582 & $14.843^{* *}$ & $0.05688^{* * *}$ & $0.25051^{* * *}$ & $-0.36578^{* * *}$ \\
\hline PX50_CG (-2) & -0.57099 & -3.487 & -7.448 & 0.00309 & -0.01329 & $-0.11514 * * *$ \\
\hline PX50_CG (-3) & -2.54849 & 2.200 & -4.270 & $0.01206^{* * *}$ & 0.02168 & -0.03702 \\
\hline WIG20_CG (-1) & $-8.47990 * *$ & -1.559 & $-12.840 * *$ & $0.03963^{* * *}$ & $-0.08181 * * *$ & $0.41354 * * *$ \\
\hline WIG20_CG (-2) & -0.68758 & 1.012 & 1.867 & $-0.01161 * * *$ & $-0.02924 * *$ & $0.09461 * * *$ \\
\hline WIG20_CG (-3) & 1.19606 & -1.935 & 3.016 & $-0.00608^{*}$ & $0.03334 * * *$ & $0.09873^{* * *}$ \\
\hline DAX_CG (-1) & -2.60157 & -8.613 & 17.313 & $-0.03973 * * *$ & $-0.47351 * * *$ & $-0.65892^{* * *}$ \\
\hline DAX_CG (-2) & $48.474^{* * *}$ & 15.300 & $35.151^{*}$ & -0.00828 & $0.94792^{* * *}$ & $1.33935^{* * *}$ \\
\hline DAX_CG $(-3)$ & 2.40211 & 11.482 & 18.020 & $0.04256^{* * *}$ & $0.65774^{* * *}$ & $0.90578^{* * *}$ \\
\hline CAC_CG (-1) & $77.732 * * *$ & $32.461 * *$ & 40.743 & $0.08387 * * *$ & $2.72796^{* * *}$ & $3.79118^{* * *}$ \\
\hline CAC_CG $(-2)$ & $-81.489 * * *$ & -25.366 & $-49.948^{*}$ & -0.02515 & $-2.09026^{* * *}$ & $-2.99945^{* * *}$ \\
\hline CAC_CG $(-3)$ & -12.711 & $-27.466^{*}$ & -16.245 & $-0.05992 * * *$ & $-1.21827^{* * *}$ & $-1.66102^{* * *}$ \\
\hline UKX_CG (-1) & $-113.780^{* * *}$ & -11.356 & -37.650 & $-0.06503 * *$ & $-2.76493 * * *$ & $-3.88030^{* * *}$ \\
\hline UKX_CG (-2) & 49.668 & 30.892 & 2.133 & $0.08778^{* * *}$ & $1.70287^{* * *}$ & $2.45123^{* * *}$ \\
\hline UKX_CG $(-3)$ & 8.697 & 7.192 & -10.319 & -0.00293 & $0.54169^{* * *}$ & $0.72130^{* * *}$ \\
\hline R2 & 0.004 & 0.010 & 0.012 & 0.229 & 0.150 & 0.212 \\
\hline R2 ADJ & 0.002 & 0.008 & 0.011 & 0.228 & 0.149 & 0.211 \\
\hline
\end{tabular}

\section{Conclusions}

In this paper, we attempted to analyse possible interrelations within three stock markets in Central and Eastern Europe and, in addition, interconnections which may exists between Western European stock markets on the one hand (DAX, CAC, UKX) and Central and Eastern European stock markets (BUX, PX-50, WIG20) on the other. The novelty of our 
paper rests mainly on the use of the five-minute tick intraday data for stock indices and on the wide range of econometric techniques employed.

Our estimation results indicate that for a common daily window composed of 72 ticks running from mid-2003 to the early 2005, no robust cointegration relationship could be established for any of the stock index pairs or for any of the extended specifications. Notwithstanding the lack of any stable long-term relation between the stock market indices under study, there are signs of short-term spillover effects both in terms of stock returns and stock price volatility. Granger causality tests show the presence of bidirectional causality for the returns as well as volatility series. However, this finding is partly mitigated by the results based on a VAR framework which includes both stock returns and stock market volatility, as they shed light on a more limited number of short-term relationships between the stock markets. In general, it appears that spillover effects are stronger from volatility to volatility as compared to contagion effects from return to return series. 


\section{References}

Affaneh, Ibrahim; Boldin, Robert; Majercak, Matej, 2003. International Investor Diversification via East European Emerging Stock Markets: An Analysis of the Short Sale versus No Short Sale Condition. Journal of Emerging Markets, 8(1): 13-24

Bala, Lakshmi and Gamini Premaratne, 2003. Stock Market Volatility: Examining North America, Europe and Asia. National University of Singapore, Department of Economics, Working Paper.

Bohl, Martin T; Henke, Harald 2003. Trading Volume and Stock Market Volatility: The Polish Case. International Review of Financial Analysis, 12(5): 513-25

Černý, Alexandr, and Michal Koblas, 2005. Stock market integration and the speed of information transmission: the role of data frequency in cointegration and Granger causality tests. Journal of International Business and Economics, 1, 110-120

Engle, R. and G. J. Lee (1999), A Permanent and Transitory Component Model of Stock Return Volatility, in R. Engle and H. White, (eds.), Cointegration, Causality, and Forecasting: A Festschrift in Honor of Clive W. J. Granger, 475-497, Oxford: Oxford University Press.

Filer, Randall K. and Jan Hanousek, 2001. Efficiency of Price Setting Based on a Simple Excess Demand Rule: The Natural Experiment of Czech Voucher Privatization, European Economic Review, Vol. 45(9), pp.1619-1646.

Hamao, Y.R., R.W.Masulis and V.K.Ng, 1990. Correlations in Price Changes and Volatility Across International Stock Markets. Review of Financial Studies, 3, 281-307

Hanousek, Jan and Němeček, Libor, 2001. Czech Parallel Capital Markets: Discrepancies And Inefficiencies. Applied Financial Economics, 11, 45-55.

Janakiramanan, S. and A.S. Lamba, 1998. An Empirical Examination of Linkages Between Pacific-Basin Stock Markets. Journal of International Financial Markets, Institutions and Money, 8, $155-173$

Kočenda, Evžen. 1999. "Residual State Property in the Czech Republic," Eastern European Economics, Vol. 37(5), pp. 6-35.

McMillan, David G. and Speight, Alan E.H., 2002. Intra-day Periodicity and Long-Run Volatility in Short Sterling Futures. Journal of Risk, 5(1): 59-74

Murinde, Victor; Poshakwale, Sunil 2001. Volatility in the Emerging Stock Markets in Central and Eastern Europe: Evidence on Croatia, Czech Republic, Hungary, Poland, Russia and Slovakia. European Research Studies, 4(3-4): 73-101

Pesaran, M.H, Y. Shin, R.J. Smith. 2001. Bounds testing approaches to the analysis of level relationships. Journal of Applied Econometrics, 16(3), 289-326.

Rockinger, M. and G. Urga (2000), The evolution of stock markets in transition economies, Journal of Comparative Economics, 28(3), 456-472.

Scheicher, Martin 2001. The Comovements of Stock Markets in Hungary, Poland and the Czech Republic. International Journal of Finance and Economics, 6(1): 27-39

Smith, Graham; Ryoo, Hyun-Jung 2003. Variance Ratio Tests of the Random Walk Hypothesis for European Emerging Stock Markets. European Journal of Finance, 9(3): 290300

Stock, J., Watson M.W. 1993. A simple estimator of cointegrating vectors in higher order integrated systems. Econometrica, 61(4): 783-820 
Syriopoulos, Theodore 2004. International Portfolio Diversification to Central European Stock Markets. Applied Financial Economics, 14(17): 1253-68

Terzi, AS. 2003. An Introduction to High-Frequency Finance, Book Review, International Review of Economics and Finance, 525-529.

Tse, Yiuman; Wu, Chunchi; Young, Allan 2003. Asymmetric Information Transmission between a Transition Economy and the U.S. Market: Evidence from the Warsaw Stock Exchange. Global Finance Journal, 14(3): 319-32.

Valachy, J., Kočenda, E., 2005. Exchange Rate Regimes and Volatility: Comparison of the selected ERM countries and the Visegrad Group. Ekonomický časopis/Journal of Economics, 53(2), 144-160.

Vojtek, M., 2004. Calibration of Interest Rate Models - Transition Market Case. CERGE-EI WP No. 237. 


\section{Appendix}

Table A1. CGARCH Results

\begin{tabular}{|c|c|c|c|c|c|}
\hline BUX & Coefficient & \multicolumn{2}{|l|}{ PX-50 } & \multicolumn{2}{|l|}{ WIG20 } \\
\hline \multicolumn{6}{|c|}{ MEAN EQUATION } \\
\hline $\mathrm{C}$ & $0.0000134^{* * *}$ & C & 0.0000074 & C & $0.0000134 * * *$ \\
\hline D_BUX & $-0.0000290^{* * *}$ & D_PX-50 & $-0.0000727^{* * *}$ & & \\
\hline _TD_120 & -0.0002860 & _TD_120 & -0.0002230 & _TD_120 & -0.0001020 \\
\hline _TD_121 & 0.0016970 & _TD_121 & $0.0009320^{* * *}$ & _TD_121 & -0.0000664 \\
\hline _TD_122 & $0.0012420 * * *$ & _TD_122 & $0.0009940^{* * *}$ & _TD_122 & $0.0011200^{* * *}$ \\
\hline _TD_123 & -0.0000396 & _TD_123 & -0.0000198 & _TD_123 & -0.0000342 \\
\hline _TD_124 & 0.0000165 & _TD_124 & 0.0000145 & _TD_124 & 0.0000005 \\
\hline _TD_187 & $0.0000273^{* * *}$ & _TD_187 & 0.0000286 & _TD_187 & 0.0000274 \\
\hline _TD_188 & $0.0000229 * * *$ & _TD_188 & 0.0000157 & _TD_188 & 0.0000285 \\
\hline _TD_189 & 0.0000009 & _TD_189 & 0.0000055 & _TD_189 & 0.0000172 \\
\hline _TD_190 & -0.0000011 & _TD_190 & -0.0000140 & _TD_190 & -0.0000179 \\
\hline _TD_191 & $-0.0000682 *$ & _TD_191 & $-0.0000693^{* *}$ & _TD_191 & -0.0000473 \\
\hline & & $\operatorname{AR}(1)$ & 0.0051150 & $\operatorname{AR}(1)$ & 0.0043340 \\
\hline & & $\operatorname{AR}(2)$ & 0.0050740 & $\operatorname{AR}(2)$ & 0.0075080 \\
\hline \multicolumn{6}{|c|}{ VARIANCE EQUATION } \\
\hline Perm: C & $0.0000006^{* * *}$ & Perm: C & $0.0000007^{* * *}$ & Perm: C & $0.0000006^{* * *}$ \\
\hline Perm: [Q-C] & 0.5000100 & Perm: [Q-C] & $0.5009560^{* * *}$ & Perm: [Q-C] & $0.5253600^{* * *}$ \\
\hline Perm: [ARCH-GARCH] & 0.0400330 & Perm: [ARCH-GARCH] & $0.0434010^{* * *}$ & Perm: [ARCH-GARCH] & $0.0836600 * * *$ \\
\hline Perm: D_BUX & $-0.0000003^{* * *}$ & Perm: D_PX-50 & $0.0000000^{* * *}$ & & \\
\hline Perm:_TD_120 & 0.0000020 & Perm:_TD_120 & -0.0000006 & Perm:_TD_120 & $-0.0000077^{* * *}$ \\
\hline Perm:_TD_121 & 0.0000004 & Perm:_TD_121 & -0.0000008 & Perm:_TD_121 & $0.0000060^{* *}$ \\
\hline Perm:_TD_122 & 0.0000005 & Perm:_TD_122 & 0.0000003 & Perm:_TD_122 & 0.0000004 \\
\hline Perm:_TD_123 & -0.0000020 & Perm:_TD_123 & $-0.0000020^{* * *}$ & Perm:_TD_123 & $-0.0000141 * * *$ \\
\hline Perm:_TD_124 & 0.0000019 & Perm:_TD_124 & $0.0000017^{* * *}$ & Perm:_TD_124 & $0.0000078^{* * *}$ \\
\hline Perm:_TD_187 & 0.0000000 & Perm:_TD_187 & $-0.0000108^{* * *}$ & Perm:_TD_187 & 0.0000144 \\
\hline Perm:_TD_188 & 0.0000002 & Perm:_TD_188 & $0.0000229 * * *$ & Perm:_TD_188 & 0.0000136 \\
\hline Perm:_TD_189 & 0.0000005 & Perm:_TD_189 & $-0.0000050^{* *}$ & Perm:_TD_189 & -0.0000006 \\
\hline Perm:_TD_190 & 0.0000003 & Perm:_TD_190 & $-0.0000063^{* * *}$ & Perm:_TD_190 & 0.0000076 \\
\hline Perm:_TD_191 & 0.0000001 & Perm:_TD_191 & $0.0000026^{* *}$ & Perm:_TD_191 & 0.0000002 \\
\hline Tran: [ARCH-Q] & 0.0399790 & Tran: [ARCH-Q] & $0.0396780^{* * *}$ & Tran: [ARCH-Q] & $0.0344560^{* * *}$ \\
\hline Tran: [GARCH-Q] & 0.0160030 & Tran: [GARCH-Q] & 0.0161260 & Tran: [GARCH-Q] & 0.0179720 \\
\hline Tran:_TD_120 & -0.0000013 & Tran:_TD_120 & 0.0000014 & Tran:_TD_120 & $0.0000108^{* * *}$ \\
\hline Tran:_TD_121 & 0.0000008 & Tran:_TD_121 & 0.0000017 & Tran:_TD_121 & 0.0000016 \\
\hline Tran:_TD_122 & 0.0000005 & Tran:_TD_122 & $0.0000005^{*}$ & Tran:_TD_122 & 0.0000009 \\
\hline Tran:_TD_123 & 0.0000020 & Tran:_TD_123 & $0.0000021^{* * *}$ & Tran:_TD_123 & $0.0000138^{* * *}$ \\
\hline Tran:_TD_124 & -0.0000009 & Tran:_TD_124 & $-0.0000007^{* * *}$ & Tran:_TD_124 & -0.0000013 \\
\hline Tran:_TD_187 & -0.0000001 & Tran:_TD_187 & $0.0000106^{* * *}$ & Tran:_TD_187 & -0.0000145 \\
\hline Tran:_TD_188 & -0.0000003 & Tran:_TD_188 & $-0.0000183^{* * *}$ & Tran:_TD_188 & $-0.0000204^{* * *}$ \\
\hline Tran:_TD_189 & -0.0000006 & Tran:_TD_189 & $-0.0000031 * * *$ & Tran:_TD_189 & $-0.0000093^{* *}$ \\
\hline Tran:_TD_190 & -0.0000006 & Tran:_TD_190 & $0.0000043^{*}$ & Tran:_TD_190 & $-0.0000122 *$ \\
\hline Tran:_TD_191 & -0.0000004 & Tran:_TD_191 & $-0.0000007 * * *$ & Tran:_TD_191 & $-0.0000058^{* * *}$ \\
\hline
\end{tabular}




\section{WILLIAM DAVIDSON INSTITUTE WORKING PAPER SERIES}

The Working Paper Series may be downloaded free of charge at: www.wdi.umich.edu

CURRENT AS OF 1/23/06

\begin{tabular}{|c|c|c|}
\hline Publication & Authors & Date \\
\hline $\begin{array}{l}\text { No. 798: Contagion Across Integration of Central \& Eastern European } \\
\text { Stock Markets: Evidence from Intraday Data }\end{array}$ & Balazs Egert and Evzen Kocenda & Nov. 2005 \\
\hline No. 797: Real Exchange Rate Misalignment: Prelude to Crisis? & David Kemme and Saktinil Roy & Oct. 2005 \\
\hline $\begin{array}{l}\text { No. 796: Balassa-Samuelson Meets South Eastern Europe, the CIS and } \\
\text { Turkey: A Close Encounter of the Third Kind? }\end{array}$ & Balázs Égert & Nov. 2005 \\
\hline $\begin{array}{l}\text { No. 795: A Comparison of Reform-Era Labor Force Participation Rates } \\
\text { of China's Ethnic Minorities and Han Majority }\end{array}$ & $\begin{array}{l}\text { Margaret Maurer-Fazio, James W. } \\
\text { Hughes and Dandan Zhang }\end{array}$ & Oct. 2005 \\
\hline $\begin{array}{l}\text { No. 794: Collective Action and Post-Communist Enterprise: } \\
\text { The Economic Logic of Russia's Business Associations }\end{array}$ & William Pyle & Sept. 2005 \\
\hline $\begin{array}{l}\text { No. 793: Equilibrium Exchange Rates in Transition Economies: } \\
\text { Taking Stock of the Issues }\end{array}$ & Baláz & Oct. 2005 \\
\hline No. 792: Bribery: Who Pays, Who Refuses, What Are The Payoffs? & Jennifer Hunt and Sonia Laszlo & Sept. 2005 \\
\hline $\begin{array}{l}\text { No. 791: Gender Differences In Personality and Earnings: Evidence } \\
\text { from Russia }\end{array}$ & Susan Linz and Anastasia Semykina & Apr. 2005 \\
\hline No. 790: Why Are Some Public Officials More Corrupt Than Others? & Jennifer Hunt & Sept. 2005 \\
\hline No. 789: Disinflation and Monetary Policy Arrangements in Romania & Daniel Daianu and Ella Kalai & Nov. 2004 \\
\hline $\begin{array}{l}\text { No. 788: Does Economic Uncertainty Affect the Decision to Bear } \\
\text { Children? Evidence from East and West Germany }\end{array}$ & $\begin{array}{l}\text { Sumon Kumar Bhaumik and Jeffrey } \\
\text { B. Nugent }\end{array}$ & Aug. 2005 \\
\hline $\begin{array}{l}\text { No. 787: Economic Reform and Changing Patterns of Labor Force } \\
\text { Participation in Urban and Rural China }\end{array}$ & $\begin{array}{l}\text { Margaret Maurer-Fazio, James } \\
\text { Hughes and Dandan Zhang } \\
\end{array}$ & Aug. 2005 \\
\hline $\begin{array}{l}\text { No. 786: The Determinants of Asset Stripping: Theory and Evidence } \\
\text { From the Transition Economies }\end{array}$ & $\begin{array}{l}\text { Nauro F. Campos and Francesco } \\
\text { Giovannoni }\end{array}$ & Aug. 2005 \\
\hline $\begin{array}{l}\text { No. 785: How to Catch Foreign Fish? FDI and Privatization in EU } \\
\text { Accession Countries }\end{array}$ & Bruno Merlevede and Koen Schoors & Aug. 2005 \\
\hline $\begin{array}{l}\text { World Bank have any impact on human development } \\
\text { tries? Some preliminary evidence from Africa }\end{array}$ & r Bhaumik & Aug. 2005 \\
\hline $\begin{array}{l}\text { No. 783: Comparative social capital: Networks of entrepreneurs and } \\
\text { investors in China and Russia }\end{array}$ & Bat Batjargal & July 2005 \\
\hline $\begin{array}{l}\text { No. 782: Exchange Rate Regimes, Foreign Exchange Volatility and } \\
\text { Export Performance in Central and Eastern Europe: Just Another Blur } \\
\text { Project? }\end{array}$ & $\begin{array}{l}\text { Balázs Égert and Amalia Morales- } \\
\text { Zumaquero }\end{array}$ & July 2005 \\
\hline $\begin{array}{l}\text { No. 781: Equilibrium Exchange Rate in the Czech Republic: How Good } \\
\text { is the Czech BEER? }\end{array}$ & Ian Babetskii and Balázs Égert & July 2005 \\
\hline $\begin{array}{l}\text { No. 780: Autonomy and Performance of Foreign Subsidiaries in five } \\
\text { Transition Countries }\end{array}$ & $\begin{array}{l}\text { Urmas Varblane, Katrin Männik, and } \\
\text { Helena Hannula }\end{array}$ & July 2005 \\
\hline $\begin{array}{l}\text { No. 779: The Political Economy of Industrial Policy in China: The Case } \\
\text { of Aircraft Manufacturing }\end{array}$ & Andrea Goldstein & July 2005 \\
\hline $\begin{array}{l}\text { No. 778: Bank Supervision Russian style: Rules versus Enforcement and } \\
\text { Tacit Objectives }\end{array}$ & $\begin{array}{l}\text { Sophie Claeys, Gleb Lanine and } \\
\text { Koen Schoors }\end{array}$ & June 2005 \\
\hline No. 777: Labor Market Trends and Institutions in Belarus & Zuzana Brixiova and Vera Volchok & June 2005 \\
\hline $\begin{array}{l}\text { No. 776: Can Vietnam Achieve One of its Millennium Development } \\
\text { Goals? An analysis of schooling dropouts of children }\end{array}$ & $\begin{array}{l}\text { Vo Tri Thanh And Trinh Quang } \\
\text { Long }\end{array}$ & June 2005 \\
\hline $\begin{array}{l}\text { No. 775: Is The Link Between Reforms And Growth Spurious? A } \\
\text { Comment }\end{array}$ & Tomasz Mickiewicz & May 2005 \\
\hline $\begin{array}{l}\text { No. 774: The Risk Aversion of Banks in Emerging Credit markets: } \\
\text { Evidence from India }\end{array}$ & $\begin{array}{l}\text { Sumon Kumar Bhaumik and Jenifer } \\
\text { Piesse }\end{array}$ & May 2005 \\
\hline $\begin{array}{l}\text { No. 773: Organized Labor and Restructuring: Coal Mines in the Czech } \\
\text { Republic and Romania }\end{array}$ & $\begin{array}{l}\text { Jan Bruha, Delia Ionascu, and } \\
\text { Byeongju Jeong }\end{array}$ & May 2005 \\
\hline $\begin{array}{l}\text { No. 772: Is Political Risk Company-Specific? The Market Side of the } \\
\text { Yukos Affair }\end{array}$ & Alexei Goriaev and Konstantin Sonin & May 2005 \\
\hline
\end{tabular}

